\title{
Gephyrin Regulates the Cell Surface Dynamics of Synaptic $\mathrm{GABA}_{\mathrm{A}}$ Receptors
}

\author{
Tija C. Jacob, ${ }^{1 \star}$ Yury D. Bogdanov, ${ }^{2 \star}$ Christopher Magnus, ${ }^{2}$ Richard S. Saliba, ${ }^{2}$ Josef T. Kittler, ${ }^{1}$ Philip G. Haydon, ${ }^{1}$ and \\ Stephen J. Moss ${ }^{1,2}$ \\ ${ }^{1}$ Department of Pharmacology, University College London, London WC1E 6BT, United Kingdom, and ${ }^{2}$ Department of Neuroscience, University of \\ Pennsylvania, Philadelphia, Pennsylvania 19104
}

\begin{abstract}
The efficacy of fast synaptic inhibition is critically dependent on the accumulation of $\mathrm{GABA}_{\mathrm{A}}$ receptors at inhibitory synapses, a process that remains poorly understood. Here, we examined the dynamics of cell surface $\mathrm{GABA}_{\mathrm{A}}$ receptors using receptor subunits modified with $\mathrm{N}$-terminal extracellular ecliptic pHluorin reporters. In hippocampal neurons, $\mathrm{GABA}_{\mathrm{A}}$ receptors incorporating pHluorin-tagged subunits were found to be clustered at synaptic sites and also expressed as diffuse extrasynaptic staining. By combining FRAP (fluorescence recovery after photobleaching) measurements with live imaging of FM4-64-labeled active presynaptic terminals, it was evident that clustered synaptic receptors exhibit significantly lower rates of mobility at the cell surface compared with their extrasynaptic counterparts. To examine the basis of this confinement, we used RNAi to inhibit the expression of gephyrin, a protein shown to regulate the accumulation of $\mathrm{GABA}_{\mathrm{A}}$ receptors at synaptic sites. However, whether gephyrin acts to control the actual formation of receptor clusters, their stability, or is simply a global regulator of receptor cell surface number remains unknown. Inhibiting gephyrin expression did not modify the total number of $\mathrm{GABA}_{\mathrm{A}}$ receptors expressed on the neuronal cell surface but significantly decreased the number of receptor clusters. Live imaging revealed that clusters that formed in the absence of gephyrin were significantly more mobile compared with those in control neurons. Together, our results demonstrate that synaptic $\mathrm{GABA}_{\mathrm{A}}$ receptors have lower levels of lateral mobility compared with their extrasynaptic counterparts, and suggest a specific role for gephyrin in reducing the diffusion of $\mathrm{GABA}_{\mathrm{A}}$ receptors, facilitating their accumulation at inhibitory synapses.
\end{abstract}

Key words: imaging; $\mathrm{GABA} ; \mathrm{GABA}_{\mathrm{A}}$ receptor; $\mathrm{GABA}$ synaptogenesis; $\mathrm{GABA}_{\mathrm{A}}$ receptor trafficking; GABAergic modulation

\section{Introduction}

$\mathrm{GABA}_{\mathrm{A}}$ receptors $\left(\mathrm{GABA}_{\mathrm{A}} \mathrm{Rs}\right)$ are pentameric hetero-oligomers that mediate the majority of fast synaptic inhibition in the brain. These receptors can be assembled from seven subunit families with multiple members: $\alpha 1-6, \beta 1-3, \gamma 1-3, \delta, \epsilon, \theta$, and $\pi$ (Sieghart and Sperk, 2002). The majority of GABA $\mathrm{A}_{\mathrm{A}}$ Rs assembled in neurons are believed to be composed of $\alpha, \beta$, and $\gamma 2$ subunits. In neurons, many of these receptor subtypes are selectively targeted to postsynaptic specializations, a process that is critical for the efficacy of synaptic inhibition and appropriate behavior in animals (Crestani et al., 1999). To date, studies on $\mathrm{GABA}_{\mathrm{A}} \mathrm{R}$ synaptic targeting have primarily focused on receptor trafficking through exo/endocytic processes (Moss and Smart, 2001; Kittler and Moss, 2003). Collectively, these approaches have revealed that $\mathrm{GABA}_{\mathrm{A}}$ Rs on neuronal plasma membranes exhibit significant constitutive endocytosis and rapid recycling, processes that

\footnotetext{
Received June 3, 2005; revised Aug. 13, 2005; accepted 0ct. 5, 2005.

This work was supported by Medical Research Council (United Kingdom), Wellcome Trust, and National Institutes of Health Grants NS 046478 and NS 048045 (S.J.M.). We thank Jim Rothman for the pHlourin construct, Sam Wilson and Dr. P. Kellam for the pGEM vector (The Windeyer Institute, University College London, London, UK), and JeanMarc Fritschy (University of Zurich, Zurich, Switzerland) for antibodies against the $G A B A_{A}$ receptor $\alpha 2$ subunit.

*T.C.J. and Y.D.B. contributed equally to this manuscript.

Correspondence should be addressed to Dr. Stephen J. Moss, Professor of Neuroscience, Department of Neuroscience, 145 Johnson Pavilion, Hamilton Walk, Philadelphia, PA 19104. E-mail: sjmoss@mail.med.upenn.edu. D0I:10.1523/JNEUROSCI.2267-05.2005

Copyright $\odot 2005$ Society for Neuroscience $\quad 0270-6474 / 05 / 2510469-10 \$ 15.00 / 0$
}

can directly modify the efficacy of synaptic inhibition (Kittler et al., 2000b, 2004).

Although these approaches have provided key insights into membrane trafficking of $\mathrm{GABA}_{\mathrm{A}} \mathrm{Rs}$, the dynamics of the cell surface receptors remains unknown. Single-particle tracking microscopy studies on glycine and AMPA-type glutamate receptors (AMPARs) have demonstrated that extrasynaptic and synaptic receptor pools have distinct membrane dynamics, and that there are significant rates of exchange between these distinct receptor populations (Meier et al., 2001; Dahan et al., 2003; Triller and Choquet, 2003).

To visualize the cell surface dynamics of $\mathrm{GABA}_{\mathrm{A}} \mathrm{Rs}$, we made ecliptic pHluorin (a pH-sensitive GFP variant)-tagged $\mathrm{GABA}_{\mathrm{A}} \mathrm{R}$ subunits to measure receptor mobility in real time (Miesenbock et al., 1998; Ashby et al., 2004a). Using fluorescence recovery after photobleaching (FRAP), our studies show that synaptic receptors have lower FRAP rates compared with extrasynaptic $\mathrm{GABA}_{\mathrm{A}} \mathrm{Rs}$, strongly suggesting lower rates of lateral mobility for synaptic receptors compared with their extrasynaptic counterparts under control conditions. To examine the molecular basis of this selective confinement of synaptic receptors, we analyzed the role of the inhibitory synaptic scaffold protein gephyrin, which has been strongly implicated in the formation of postsynaptic inhibitory specializations (Essrich et al., 1998; Kneussel et al., 1999; Levi et al., 2004). Using RNA interference (RNAi), we reveal that de- 
creasing gephyrin expression did not modify the total cell surface expression levels of $\mathrm{GABA}_{\mathrm{A}}$ Rs but significantly reduced the number of synaptic receptor clusters. Moreover, remaining receptor clusters exhibited enhanced mobility. Together, our results reveal that synaptic and extrasynaptic $\mathrm{GABA}_{\mathrm{A}} \mathrm{Rs}$ exhibit distinct cell surface dynamics and that gephyrin plays a critical role in reducing the mobility of $\mathrm{GABA}_{\mathrm{A}} \mathrm{R}$ clusters, thereby promoting the formation of postsynaptic inhibitory specializations.

\section{Materials and Methods}

Cell culture and transfection. Hippocampal cultures were prepared as described previously (Banker and Goslin, 1998). Neurons were nucleofected with constructs as described previously (Kittler et al., 2004) or transfected with Effectene according to the manufacturer's specifications (Qiagen, Valencia, CA). Mammalian COS-7 and HEK 293 cells were transfected by electroporation as described previously (Kittler et al., 2000a).

Electrophysiology. Coverslips containing the transfected HEK 293 cells were transferred to a recording chamber mounted on the stage of an inverted microscope. The external solution contained the following: 120 mм NaCl, 3 mм KCl, 5 mм HEPES, $23 \mathrm{~mm} \mathrm{NaHCO}_{3}, 11$ mм glucose, 1.2 $\mathrm{mm} \mathrm{MgCl}_{2}, 2.5 \mathrm{mM} \mathrm{CaCl}_{2}$, and $500 \mathrm{~nm}$ TTX continuously oxygenated with a mixture of $95 \% \mathrm{O}_{2} / 5 \% \mathrm{CO}_{2}$. The recording chamber is perfused at a rate of $5-10 \mathrm{ml} / \mathrm{min}$ and maintained at $32^{\circ} \mathrm{C}$ (Kittler et al., 2000b; Bedford et al., 2001). The internal solution comprises the following (in $\mathrm{mm}): 80$ potassium acetate, $30 \mathrm{KCl}, 40 \mathrm{HEPES}, 1 \mathrm{MgCl}_{2}, 4 \mathrm{ATP}\left(\mathrm{Mg}^{2+}\right.$ salt), and $2 \mathrm{ATP}\left(\mathrm{Na}^{+}\right.$salt) (adjusted to $\mathrm{pH} 7.3-7.4$ with $\mathrm{KOH}$ and to 280 mOsm with K acetate). Pipettes had a resistance of 3-4.5 $\mathrm{M} \Omega$ when filled with this internal solution. Patch-clamp experiments were performed in the whole-cell configuration using an Axopatch 200A amplifier. Series resistance and membrane capacitance are partially compensated (70$80 \%$ ), and current traces are low-pass filtered at $2 \mathrm{kHz}$ using a four-pole Bessel filter. The holding potential in all experiments was $-70 \mathrm{mV}$. Drugs were rapidly applied to single cells using a modified U-tube, placed 50$100 \mu \mathrm{m}$ away from the cell of interest (Kittler et al., 2000b; Bedford et al., 2001).

FRAP studies and live imaging. Measurements were made on 10-14 d in vitro (DIV) hippocampal neurons or HEK 293 cells transfected with the relevant expression constructs. Expressing cells were maintained at $37^{\circ} \mathrm{C}$ on a heated stage continuously perfused with oxygenated media and imaged using a confocal microscope. Active presynaptic terminals of hippocampal neurons were stained in $50 \mathrm{~mm} \mathrm{KCl}, 50 \mathrm{~mm} \mathrm{NaCl}$, $2 \mathrm{~mm} \mathrm{CaCl}_{2}, 1 \mathrm{~mm} \mathrm{MgCl}_{2}, 20$ mм HEPES, pH 7.3, supplemented with 10 $\mu \mathrm{M}$ [N-(3-triethylammoniumpropyl)-4-(6-(4-diethylamino)phenyl)hexatrienyl)pyridinium dibromide] (FM4-64) for $3 \mathrm{~min}$, and then washed three times in the same buffer lacking dye and $\mathrm{KCl}$ (Mohrmann et al., 2003). A receptor cluster was defined as being $\sim 0.5-2 \mu \mathrm{m}$ in length, and approximately twofold to threefold more intense than background diffuse fluorescence. Synaptic clusters were colocalized with or directly apposed to FM4-64 staining. For FRAP, we measured the fluorescence intensity of both synaptic and diffuse extrasynaptic receptor pools. The regions of interest (ROIs) for synaptic pools were $1-2 \mu \mathrm{m}^{2}$ in size and centered on an individual FM4-64-positive cluster. ROIs were first scanned with an argon 488 laser at $5-10 \%$ power for 5 cycles to determine a measurement of initial fluorescence intensity in the ROI. This value was then taken as $100 \%$. Next, ROIs were subjected to 10 cycles with argon 488 laser at $100 \%$ to photobleach the ROI. The fluorescence intensity of the ROI was then measured every $60 \mathrm{~s}$ at $5-10 \%$ laser power for up to 20 min to measure fluorescence recovery relative to the initial settings in the ROI. FM4-64 staining was visualized in parallel using a HeNe laser (543 $\mathrm{nm}$ ) and a long-pass filter at $680 \mathrm{~nm}$. For data processing, all confocal images were exported to the software program MetaMorph (Universal Imaging, Downingtown, PA) for analysis and quantification of fluorescence levels. All values of fluorescence intensity in the ROIs were obtained by subtracting the background fluorescence from an identical membrane area that did not display detectable $\mathrm{GABA}_{\mathrm{A}} \mathrm{R}$ fluorescence. The fluorescence recovery at every time point was calculated according to the following equation: $100 \times\left[\left(I_{t}-I_{0}\right) /\left(I_{c}-I_{0}\right)\right]$, where $I_{t}$ represents fluorescence intensity in the ROI at the given time point, $I_{0}$ represents the intensity of fluorescence in ROI after photobleaching, and $I_{c}$ represents the average value of five measurements of the fluorescence intensity in the ROI before photobleaching.

Immunoblot analysis and biotinylation. Immunoblot analysis and biotinylation assays were performed as described (Kittler et al., 2000b; Jovanovic et al., 2004) using the following primary antibodies: polyclonal $\mathrm{GABA}_{\mathrm{A}} \mathrm{R} \beta 3$-specific antibody $(1 \mu \mathrm{g} / \mathrm{ml})$, polyclonal gephyrin antibody (1:200; Santa Cruz Biotechnology, Santa Cruz, CA), and polyclonal 143-3 $\zeta$ isoform antibody (1:2000; Santa Cruz Biotechnology). Antibodies were detected with ${ }^{125} \mathrm{I}$-coupled anti-rabbit IgG, quantified by PhosphorImager analysis, and normalized to the levels of 14-3-3 $\zeta$ isoform levels. Cell surface biotinylation of hippocampal neurons using NHS (sulfo- $N$ hydroxysulfosuccinimidyl)-biotin has also been outlined previously in detail (Jovanovic et al., 2004; Rathenberg et al., 2004). The amount of biotinylated $\mathrm{GABA}_{\mathrm{A}} \mathrm{R} \beta 3$ subunit and AMPAR glutamate receptor 1 (GluR1) subunit was determined by immunoblotting with $\beta 3$-specific and GluR1-specific antibodies (1:100; polyclonal anti-GluR1 AMPAR; Chemicon, Temecula, CA), followed by ${ }^{125}$ I-coupled anti-rabbit IgG, and PhosphorImager analysis.

Immunocytochemistry. HEK 293 cells and transfected hippocampal neurons were processed for immunohistochemistry under both permeabilized or nonpermeabilized conditions as described previously (Kittler et al., 2000b). The following primary antibodies were used: rabbit antivesicular inhibitory amino acid transporter (1:1000; kindly provided by Dr. B. Gasnier, Institut de Biologie Physico-Chimique, Paris, France), guinea pig anti-GABA $\mathrm{R} \alpha 2$ (1:4000; kindly provided by Prof. J.-M. Fritschy, University of Zurich, Zurich, Switzerland), rabbit anti-GluR1 AMPAR (1:100; Chemicon), monoclonal anti-gephyrin (mAb7a; 1:150; Connex, Martinsreid, Germany), and both rabbit anti-GFP and monoclonal anti-synapsin 1 (hybridoma; catalog \#106 021) at 1:500 (Synaptic Systems, Gottingen, Germany).

Image acquisition and analysis of fixed neurons. Confocal images of immunostained neurons were taken using a $60 \times$ objective, acquired with Bio-Rad (Hercules, CA) software and analyzed with MetaMorph. Receptor clusters were identified as described above for live imaging. Synaptic clusters colocalized with or apposed presynaptic marker staining. Clusters further than $1 \mu \mathrm{m}$ from presynaptic marker staining were considered extrasynaptic. Identical confocal image acquisition settings were used for RNAi and control neurons from the same culture. All channels of an image were first background subtracted, and then thresholded and stacked to determine apposition of postsynaptic receptor subunits with a presynaptic marker. The threshold value was determined for each culture and used for all images from that culture. Quantification of receptor cluster and presynaptic marker density was performed on neuronal processes extending from the cell body that were in focus (average lengths ranged from 40 to $70 \mu \mathrm{m}$ ), with the final synaptic receptor density being provided with the unit length of $50 \mu \mathrm{m}$.

Plasmids. Gephyrin hairpin primers and control hairpin primers were synthesized (MWG-Biotech, Milton Keynes, UK) and inserted between unique SalI and XbaI sites downstream of the RNA polymerase III U6 promoter in the short hairpin RNA (shRNA) plasmid pGEM (kindly provided by S. Wilson and P. Kellam, The Windeyer Institute, University College London). pGEM was first digested with SalI and blunt ended, so that the required guanosine is retained at the +1 position of the U6 promoter immediately before the hairpin cassette. The hairpin primers are designed in the following orientation: $5^{\prime}$ sense strand, 8 bp loop containing the HindIII site for screening purposes, antisense strand, and finally five thymidines at the $3^{\prime}$ end encoding a transcription termination sequence. Immediately downstream of the $\mathrm{XbaI}$ site, five thymidines encode a stem terminator, to prevent any read-through caused by inefficient termination. The gephyrin shRNA target regions corresponded to three evolutionarily conserved sequences (rat, mouse, and human), each in a different region of the gephyrin mRNA (gi:12408325). The target regions for the gephyrin shRNA plasmids correspond to the following coding base pairs: \#1, base pairs 84-110; \#2, base pairs 478-502; and \#3, base pairs 1640-1666. The control RNAi (pControl) vector corresponds to enhanced green fluorescent protein (eGFP) coding base pairs 139-160 ( $5^{\prime}$-TTCATCTGCACCACCGGCAAGC-3'). pGEPH1 was generated by 
standard molecular biology cloning techniques, inserting eGFP into the \#3 gephyrin shRNA plasmid.

${ }_{\mathrm{pHGFP}} \beta 3$, DsRed-tagged gephyrin (DsRGep), and ${ }^{\mathrm{PHGFP}} \gamma 2$ were expressed using a cytomegalovirus (CMV)-based expression vector as described previously (Kittler et al., 2000a). The ${ }_{\text {PHGFP }} \beta 3$ construct was made by inserting pHluorin between amino acids 4 and 5 of the mature $\beta 3$ subunit by PCR amplification with primers containing flanking BglII and NotI sites to yield $\mathrm{pCON} \beta 3$. pGEPH $\beta 3$ is a version of this plasmid that also expresses the \#3 gephyrin shRNA. pCON $\gamma 2$ was made by inserting pHluorin between amino acids 4 and 5 of the $\gamma 2 \mathrm{~L}$ subunit by PCR amplification with primers containing NotI and XhoI sites. pGEPH $\gamma 2$, the plasmid encoding ${ }^{\mathrm{PHGFP}} \gamma 2$ and the \#3 gephyrin shRNA, was constructed by standard molecular biology cloning techniques, inserting the \#3 gephyrin shRNA into pCON $\gamma 2$. For the DsRGep plasmid, a gephyrin cDNA construct was amplified with primers allowing subsequent insertion into pDsRed2-N1 (Clontech, Cambridge, UK). All constructs were sequenced to confirm the fidelity of the final expression constructs.

\section{Results}

\section{Analyzing $\mathrm{GABA}_{\mathrm{A}} \mathrm{R}$ expression in}

hippocampal neurons with

pHluorin reporters

To analyze the cell surface dynamics of $\mathrm{GABA}_{\mathrm{A}} \mathrm{Rs}$, we introduced a $\mathrm{pH}$-sensitive GFP variant, ecliptic pHluorin, between amino acids 4 and 5 of mature $\mathrm{GABA}_{\mathrm{A}} \mathrm{R}$ subunits (supplemental Fig. 1 $a$, available at www.jneurosci.org as supplemental material). We have previously shown the addition of GFP, myc, or FLAG epitopes to this domain of $\mathrm{GABA}_{\mathrm{A}} \mathrm{R} \alpha, \beta$, and $\gamma 2$ subunits is functionally silent (Kittler et al., 2000a). Ecliptic pHluorin produces effectively no fluorescence at acidic $\mathrm{pH}$ values $(\mathrm{pH}<6.5)$ characteristic of vesicular compartments (Miesenbock et al., 1998). As the $\mathrm{N}$ terminus of $\mathrm{GABA}_{\mathrm{A}} \mathrm{R}$ subunits resides in the vesicular lumen, the pHluorin-tagged receptor subunits should produce minimal fluorescence during trafficking and a robust fluorescent signal at the cell surface.

Expression of pHluorin-tagged $\beta 3\left({ }^{{ }^{\mathrm{HGFP}}} \beta 3\right)$ and $\gamma 2$ $\left({ }^{\mathrm{PHGFP}} \gamma 2\right)$ in HEK 293 cells produced proteins of 85 and $79 \mathrm{kDa}$, respectively, in agreement with the predicted molecular mass of these proteins (supplemental Fig. 1b, available at www. jneurosci.org as supplemental material). ${ }^{\mathrm{pHGFP}} \beta 3$ subunits were able to robustly access the cell surface in HEK 293 cells as measured by immunohistochemistry but were also detected within intracellular compartments as shown previously (supplemental Fig. 1c, available at www.jneurosci.org as supplemental material) (Bedford et al., 2001). To analyze whether fluorescence in cells expressing ${ }^{\mathrm{pHGFP}} \beta 3$ derives from cell surface receptors, we used fluorescence quenching with the vital dye trypan blue, which is excluded from living cells (Nuutila and Lilius, 2005). Under control conditions, expressing cells exhibited strong endogenous green fluorescence (supplemental Fig. 1d, panels 1 and 2, available at www.jneurosci.org as supplemental material). After exposure to trypan blue, fluorescence was abolished in live cells that

\section{C}
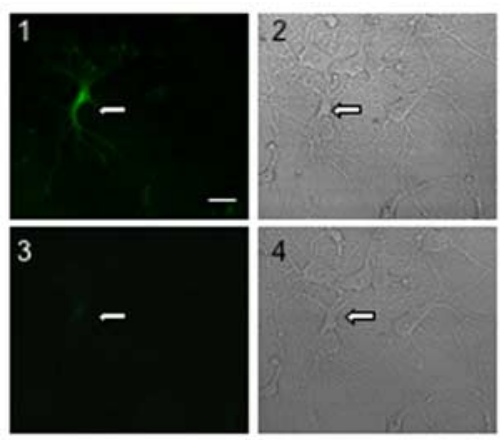

d
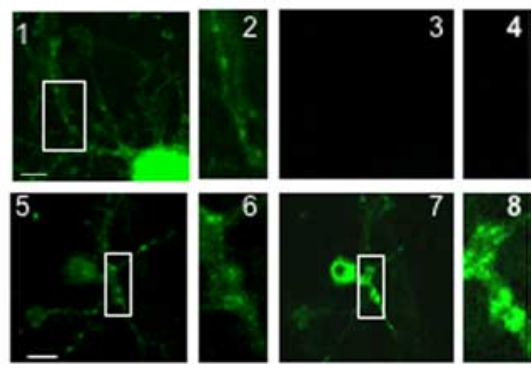

Figure 1. Characterization of pHluorin-tagged GABA $A_{A}$ subunits. $\boldsymbol{a}, 14$ DIV hippocampal neurons expressing ${ }^{\text {pHGFP }} \beta 3$ were stained with FM4-64 to label active presynaptic terminals and then imaged at $37^{\circ} \mathrm{C}$ by confocal microscopy. ${ }^{\text {pHGFP }} \beta 3$ fluorescence

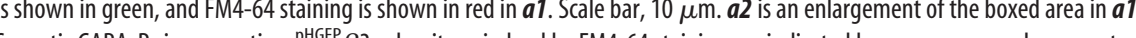
clusters in three independent transfections for each subunit). Receptor localization was also measured using anti-GFP antibody 列 uorescence images, whereas $\mathbf{c} 2$ and $\mathbf{c} 4$ represents bright-field images of the same cells. Scale bar, $15 \mu \mathrm{m}$. The arrow indicates a and imaged again after $180 \mathrm{~s}(\mathbf{d} \mathbf{7}) . \mathbf{d} \mathbf{2}, \mathbf{d 4}, \mathbf{d 6}$, and $\mathbf{d} \mathbf{8}$ represent enlargements of the boxed areas in $\mathbf{d 1}, \mathbf{d} \mathbf{3}, \mathbf{d 5}$, and $\mathbf{d 7}$, respectively. Scale bars: $\boldsymbol{d 1}, 8 \mu \mathrm{m} ; \boldsymbol{d 5}, 16 \mu \mathrm{m}$.

did not accumulate this dye within their cytoplasm (supplemental Fig. $1 d$, panels 3 and 4 , available at www.jneurosci.org as supplemental material). Together, these results suggest that pHluorin-tagged $\mathrm{GABA}_{\mathrm{A}} \mathrm{R}$ subunits principally exhibit fluorescence on the cell surface.

To address whether ${ }^{\mathrm{pHGFP}} \beta 3$ subunits are capable of assembling with $\alpha 1$ and $\gamma 2$ subunits to form functional benzodiazepine-sensitive $\mathrm{GABA}_{\mathrm{A}}$ receptors, we used patchclamp recording to measure GABA-induced currents $\left(I_{\mathrm{GABA}}\right)$ from HEK 293 cells expressing receptor $\alpha 1 \beta 3 \gamma 2$ and $\alpha 1$ ${ }_{\mathrm{pHGFP}} \beta 3 \gamma 2$ subunits. Using dose-response analysis, it was evident that receptors containing $\beta 3$ or ${ }^{\mathrm{PHGFP}} \beta 3$ subunits had similar $\mathrm{EC}_{50}$ values for GABA of $8 \pm 4.5$ and $6 \pm 3.5 \mu \mathrm{M}$ (mean \pm SEM; $n=4$ ) and maximal currents (supplemental Fig. $1 e$, available at www.jneurosci.org as supplemental material). To measure the incorporation of the $\gamma 2$ subunit, we compared the potency of benzodiazepines to enhance $\mathrm{I}_{\mathrm{GABA}}$ at $\mathrm{EC}_{20}$ agonist concentrations. Flurazepam produced very similar robust, dose-dependent enhancements of $I_{\mathrm{GABA}}$ for receptors composed of $\alpha 1 \beta 3 \gamma 2$ and $\alpha 1{ }^{\text {PHGFP }} \beta 3 \gamma 2$ subunits (supplemental Fig. $1 f$, available at www. jneurosci.org as supplemental material). Together, these observations suggest that the addition of pHluorin at the $\mathrm{N}$ terminus of the $\beta 3$ subunit does not compromise receptor assembly or func- 
a

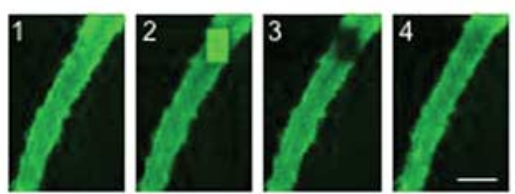

b

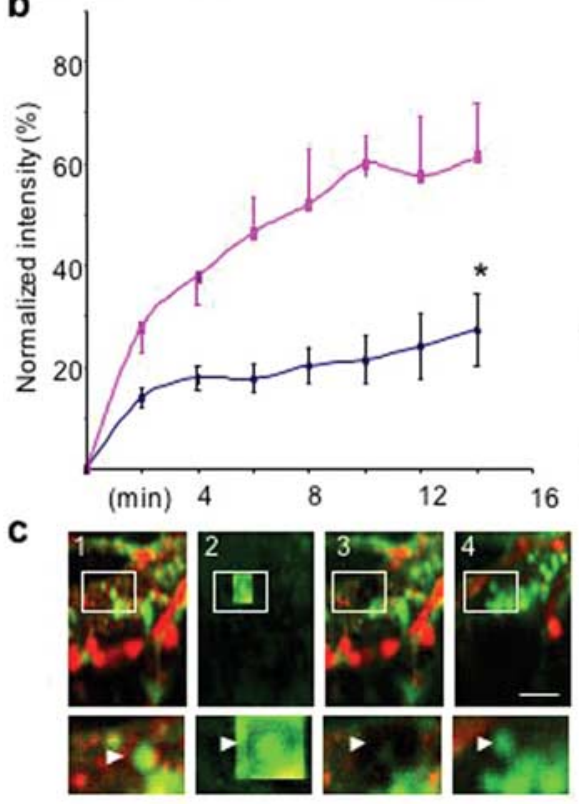

d

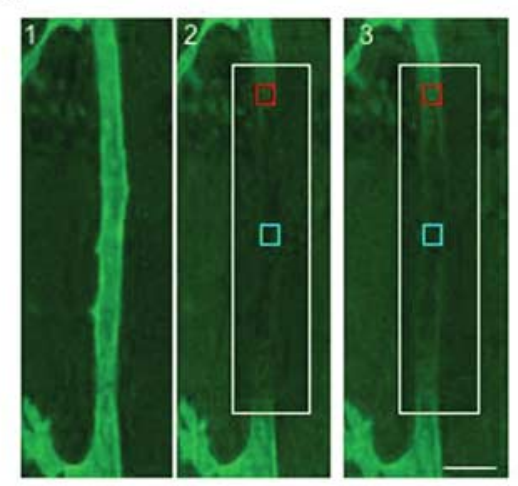

e

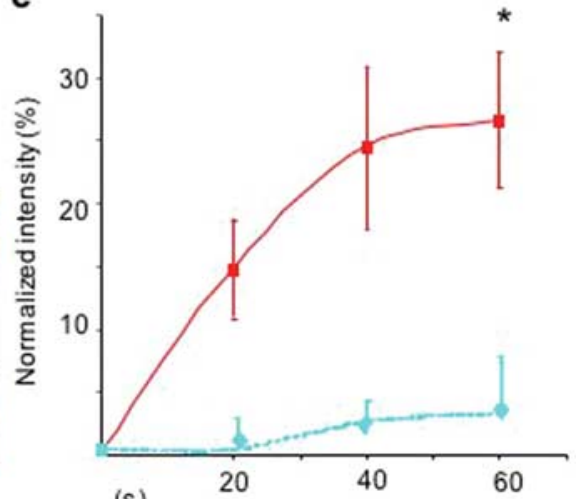

(s)

Figure 2. Synaptic and extrasynaptic GABA $A_{A} R$ s exhibit differing FRAP rates. $\boldsymbol{a}$, FRAP for extrasynaptic $G A B A_{A}$ Rs containing ${ }_{\text {pHGFP }} \beta 3$ subunits. Areas of $2-3 \mu \mathrm{m}^{2}$ were imaged from areas of $10-14$ DIV hippocampal neurons exhibiting diffuse ${ }^{\text {pHGFP }} \beta 3$ fluorescence over a 15 min time period. $\boldsymbol{a} \mathbf{1}$, Control (initial fluorescence); $\boldsymbol{a} \mathbf{2}$, bleaching; $\boldsymbol{a} \mathbf{3}, 0 \mathrm{~min}$ after bleaching; $\boldsymbol{a} 4,15 \mathrm{~min}$ after photobleaching. Scale bar, $10 \mu \mathrm{m}$. $\boldsymbol{b}$, Synaptic and extrasynaptic $\mathrm{GABA}_{\mathrm{A}}$ Rs containing ${ }^{\text {PHGFP }} \beta 3$ subunits exhibit distinct FRAP. Recovery of fluorescence for extrasynaptic receptors (green) and for synaptic receptors (blue) was measured over a 15 min time period as outlined in $\boldsymbol{a}$. Data were compared with the signal obtained before photobleaching, which was given a value of $100 \%$. The asterisk indicates significant difference from extrasynaptic receptors ( $p<0.01$, Student's $t$ test; $n=11-14)$. Error bars indicate SEM. c, FRAP for synaptic GABA $A_{A}$ Rs containing ${ }^{\text {PHGFP }} \beta 3$ subunits. Hippocampal neurons expressing ${ }^{\text {PHGFP }} \beta 3$ subunits (green) were stained with FM4-64 (red). Areas of $2 \mu \mathrm{m}^{2}$ that contained a single cluster of ${ }^{\mathrm{PHGFP}} \beta 3$ fluorescence adjacent to FM4-64 fluorescence (arrowhead) were then subjected to photobleaching, and FRAP was measured over a time course of 15 min as outlined in $\boldsymbol{a}$. Scale bar, $5 \mu \mathrm{m}$. The bottom panels are enlargements of the boxed areas in the top panels. $\boldsymbol{d}, \boldsymbol{e}$, FRAP for ${ }^{\text {pHGFP }} \beta 3$ subunits is dependent on location within the photobleached area. Areas of $30 \times 10 \mu \mathrm{m}$ on noninnervated domains of $10-14$ DIV neurons expressing ${ }^{\text {PHGFP }} \beta 3$ were imaged at $37^{\circ}$. FRAP was measured for $2-3 \mu \mathrm{m}^{2}$ areas within the center of the photobleached area (blue) or at the periphery (red) over a 1 min time period every $10 \mathrm{~s}$ (see supplemental movie 1, available at www.jneurosci.org as supplemental material). Images taken immediately before photobleaching are shown in $\boldsymbol{d} \mathbf{1}$, and at 0 and 1 min after photobleaching in $\mathbf{d} \mathbf{2}$ and $\mathbf{d} \mathbf{3}$, respectively. Scale bar, $9 \mu \mathrm{m}$. , Data acquired at various time periods for central (blue) and peripheral areas (red) were analyzed over the recording period and compared with the original starting intensity that was given a value of $100 \%$. The asterisk indicates significant difference from central domains ( $p<0.01$, Student's $t$ test; $n=4-5$ from 3 independent transfections). Error bars indicate SEM.

tion, consistent with our previous studies on receptors that incorporate GFP-tagged $\gamma 2$ subunits (Kittler et al., 2000a).

We analyzed the synaptic targeting of pHluorin-tagged $\beta 3$ $\left({ }^{\mathrm{pHGFP}} \beta 3\right)$ and $\gamma 2\left({ }^{\mathrm{PHGFP}} \gamma 2\right)$ subunits expressed under the CMV promoter in live neurons using FM4-64 to selectively stain active synapses (Lagnado et al., 1996; Mammen et al., 1997; Scotti and Reuter, 2001). This methodology produced robust staining of active presynaptic terminals, and using this marker, it was evident ${ }_{\mathrm{pHGFP}} \beta 3$ subunits exhibited both synaptic and extrasynaptic localization (Fig. 1a). The percentage of ${ }^{\mathrm{pHGFP}} \beta 3$ clusters colocalizing with FM4-64 signals was determined to be $20.9 \pm 5.4 \%$ (mean \pm SEM; 200 clusters counted from three independent transfections). Similar levels of colocalization were also found using immunofluorescence in fixed neurons $(24.6 \pm 6.4 \%)$

(mean \pm SEM; 150 clusters counted; three independent transfections; Fig. 1b). Live imaging of ${ }^{\mathrm{PHGFP}} \gamma 2$-expressing neurons showed that $84.3 \pm 5.1 \%$ (mean \pm SEM; 150 clusters counted from three independent transfections) of ${ }^{\mathrm{pHGFP}} \gamma 2$ clusters were synaptic as determined by their colocalization with FM4-64 (Fig. 1b). Using immunohistochemistry in fixed neurons, a similar figure of $86.5 \pm 9.8 \%$ was seen (mean \pm SEM; 220 clusters counted from four transfections). Therefore, these studies revealed a significantly higher level of synaptic targeting of ${ }^{\mathrm{PHGFP}} \gamma 2$ compared with ${ }^{\text {PHGFP }} \beta 3$ subunits $(p<0.01)$, as measured using two independent methodologies, and are consistent with observations of their endogenous equivalents (Danglot et al., 2003).

To verify that pHluorin-tagged $\mathrm{GABA}_{\mathrm{A}} \mathrm{Rs}$ principally exhibit fluorescence at the cell surface of neurons, we performed a number of control experiments. First, we examined the ability of trypan blue to quench fluorescence of ${ }^{\mathrm{PHGFP}} \beta 3$ subunits expressed in hippocampal neurons with obvious pyramidal morphology. Treatment of neurons with this agent, followed by extensive washing, completely blocked fluorescence emissions for this subunit in living neurons at $37^{\circ} \mathrm{C}$ (Fig. 1c). In addition, decreasing the extracellular $\mathrm{pH}$ with acidic media $(\mathrm{pH}<6.0)$, also blocked fluorescence signals in neurons over a $90 \mathrm{~s}$ time course (Fig. 1d, panels $1-4)$. This is consistent with the selective detection of cell surface receptors (Ashby et al., 2004b). Importantly, we have previously established using redox dyes that treatment with acidic media $(\mathrm{pH}<6.0)$ over the same time course does not significantly alter intracellular $\mathrm{pH}$ in neurons (Amato et al., 1999). The effect of increasing the $\mathrm{pH}$ of intracellular compartments was also tested by exposing neurons to external $\mathrm{NH}_{4} \mathrm{Cl}$. During a $180 \mathrm{~s}$ time course, a significant increase in intracellular fluorescence signals for neurons expressing pHGFP $\beta 3$ subunits was observed, consistent with $\mathrm{NH}_{4} \mathrm{Cl}$ treatment unmasking previously nonfluorescent populations of $\mathrm{GABA}_{\mathrm{A}} \mathrm{Rs}$ in either the secretory and/or endocytic pathway (Fig. 1d, panels 5-8). These results are consistent with previous studies that demonstrated constitutive endocytosis and recycling of $\mathrm{GABA}_{\mathrm{A}} \mathrm{Rs}$, strongly suggesting a large intracellular pool of $\mathrm{GABA}_{\mathrm{A}} \mathrm{Rs}$ in hippocampal neurons (Kittler et al., 2000b, 2004). Together, these approaches suggest that pHluorin-tagged $\mathrm{GABA}_{\mathrm{A}} \mathrm{R}$ subunits are selective markers for cell surface receptors populations in hippocampal neurons.

\section{Synaptic and extrasynaptic $\mathrm{GABA}_{\mathrm{A}} \mathrm{Rs}$ exhibit differential rates of lateral mobility}

We exploited the ability of ${ }^{\mathrm{PHGFP}} \beta 3$ subunits to robustly access both extrasynaptic and synaptic sites (Fig. 1) to compare the 
dynamics of these receptor pools by performing FRAP studies. It has been established that extrasynaptic $\mathrm{GABA}_{\mathrm{A}} \mathrm{Rs}$ are found as diffuse staining, but extrasynaptic receptor clusters containing $\beta 3$ or $\gamma 2$ subunits are also evident, and some of these clusters are associated with the inhibitory scaffold protein gephyrin (Kneussel et al., 1999; Danglot et al., 2003). Therefore, to control for this evident heterogeneity, we chose to measure the mobility of diffuse ${ }^{\mathrm{pHGFP}} \beta 3$ fluorescence populations only. This was achieved by selecting ROIs of $1-2 \mu \mathrm{m}^{2}$ that were not opposed to FM4-64-positive presynaptic terminals and were at least $5 \mu \mathrm{m}$ away from the nearest cluster. FRAP for this receptor population was rapid with recovery to $65.3 \pm 12.2 \%$ (mean \pm SEM; $n=11-14$ from four independent transfections) of the initial value being seen in $15 \mathrm{~min}$ (Fig. $2 a, b)$. These results suggest that diffuse, nonclustered $\mathrm{GABA}_{\mathrm{A}} \mathrm{Rs}$ containing ${ }^{\mathrm{pHGFP}} \beta 3$ subunits in neurons are highly mobile. To measure FRAP for synaptic receptors, single clusters opposed to FM4-64 staining centered in an area of membrane between 1 and $2 \mu \mathrm{m}^{2}$ were bleached at 488 $\mathrm{nm}$. Recovery of fluorescence in this area was measured for GFP emission at $37^{\circ} \mathrm{C}$ during a time course of $15 \mathrm{~min}$ (Fig. $2 c$ ). In the majority $(80 \%)$ of neurons, up to $20.7 \pm 4.0 \%$ (mean \pm SEM; $n=11-14$; four independent transfections) of the original fluorescence intensity was evident for synaptic $\mathrm{GABA}_{\mathrm{A}} \mathrm{R}$ pools containing ${ }^{\mathrm{PHGFP}} \beta 3$ subunits within $15 \mathrm{~min}$ (Fig. $2 b, c)$. This value is significantly different from the FRAP rate observed for extrasynaptic receptors $(p<0.01)$. It should be noted that loss of FM4-64 staining was observed over the time course of these experiments (15 min), consistent with published studies showing the labile nature of this live stain (Lagnado et al., 1996; Mammen et al., 1997; Scotti and Reuter, 2001). No additional recovery of signal for synaptic receptors was seen up to $60 \mathrm{~min}$ after photobleaching (data not shown). In the remaining $20 \%$ of neurons analyzed, little recovery $(<5 \%)$ was observed. To provide evidence on the origins of newly fluorescent receptors, we analyzed FRAP in membrane regions at differing locations within the photobleached area, on noninnervated neuronal membrane domains. These data showed that regions of membrane in the center of bleached areas exhibited slower rates of FRAP compared with peripheral domains of the same size (Fig. $2 d$,e; supplemental movie 1, available at www.jneurosci.org as supplemental material), suggesting that FRAP arises from receptor lateral mobility not exocytosis. Together, these results illustrate that synaptic $\mathrm{GABA}_{\mathrm{A}} \mathrm{R}$ clusters containing $\beta 3$ subunits show lower rates of FRAP compared with the

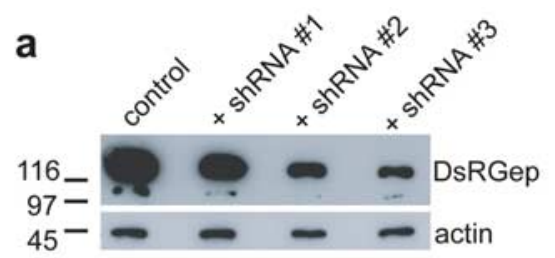

b
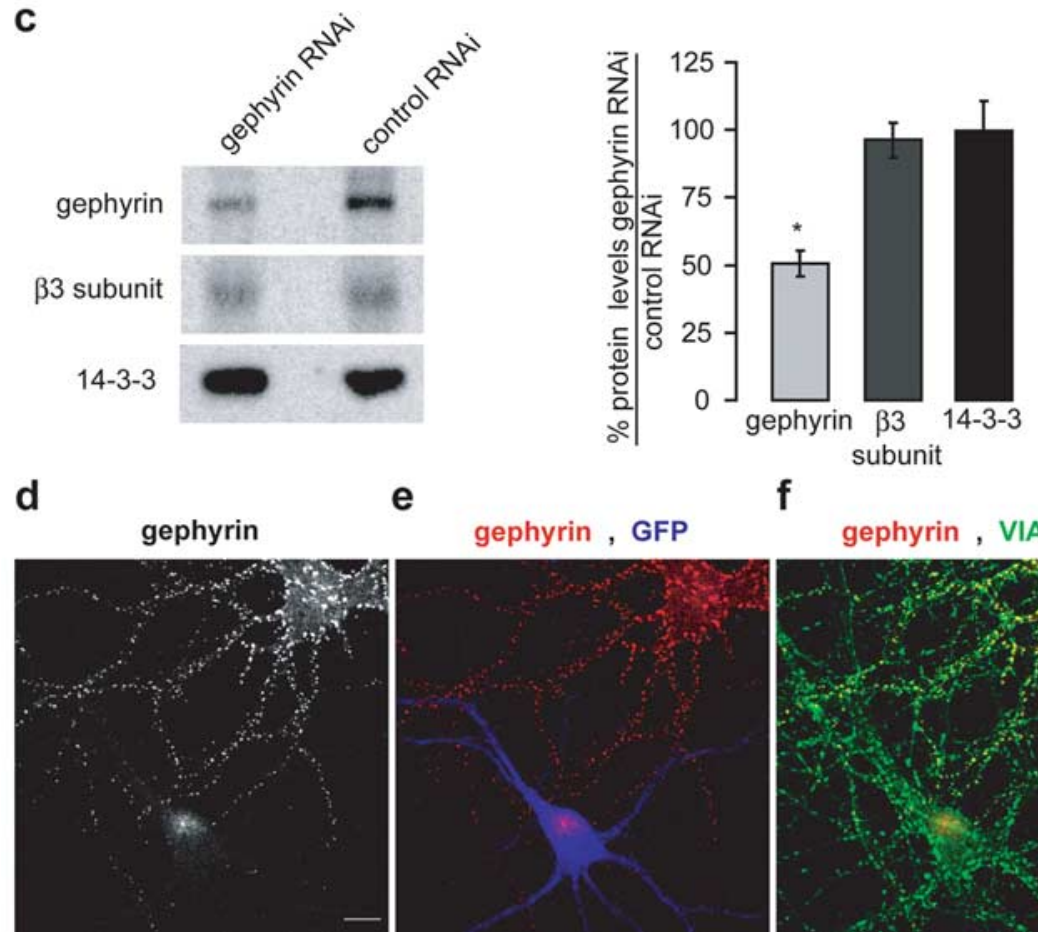

e gephyrin, GFP
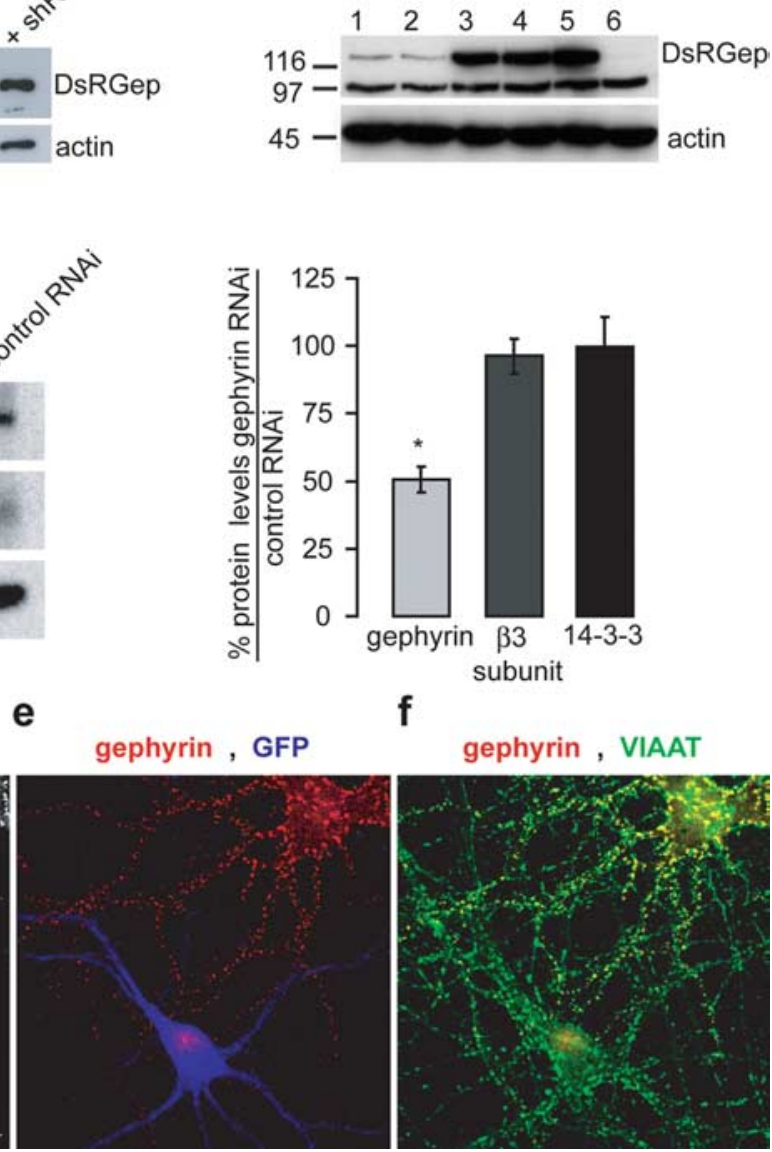

Figure 3. Gephyrin RNAi in COS-7 cells and neurons. $\boldsymbol{a}$, Western blot analysis of COS-7 cell lysates transfected with a plasmid encoding DsRGep alone or cotransfected with a gephyrin shRNA plasmid. Three different gephyrin shRNA plasmids were tested (shRNA \#1-3). The control lane was from cells transfected with DsRGep. The remaining three lanes were cotransfected with DsRGep and a shRNA vector (labeled as + shRNA \#1-3). Gephyrin RNAi efficiently knocked down DsRed-tagged gephyrin levels (122 kDa band) but did not affect endogenous actin levels ( $44 \mathrm{kDa}$ band). The immunoblot is representative of three independent experiments. $\boldsymbol{b}$, Western blot analysis of COS-7 cell lysates cotransfected with DsRGep and the gephyrin shRNA vector that also expresses eGFP (pGEPH1). Lanes 1 and 2 were cotransfected with DsRGep and pGEPH1. Lanes 3 and 4 were cotransfected with DsRGep and the control RNAi vector (pControl). In lane 5, DsRGep was transfected alone. Lane 6 shows untransfected cell lysate. pGEPH1 efficiently knocked down cotransfected DsRGep levels but did not affect endogenous actin levels. pControl had no effect on DsRGep levels or actin levels. The lower band running at $97 \mathrm{kDa}$ is endogenous gephyrin, which appears mostly unaffected by gephyrin RNAi. This is likely because of the vast excess of DsRGep that is more efficiently targeted by RNAi. Transfections and Western blots were done in triplicate. $c$, Western blot analysis of lysates from 20 DIV hippocampal neurons nucleofected with pGEPH1 (gephyrin RNAi) or pControl (control RNAi) at plating. A 50\% decrease in gephyrin levels was observed, whereas $\beta 3$ $G A B A_{A} R$ subunit levels were not significantly altered. 14-3-3 levels also remained unchanged. The panel to the left of the histogram shows a representative immunoblot for gephyrin, $\beta 3$, and 14-3-3 from one experiment. This experiment was performed six independent times, with cultures nucleofected with pGEPH1 and pControl. For each experiment, Western blot analysis was performed in triplicate. The asterisk indicates significant difference from control cells $(p<0.01$, Student's $t$ test). Error bars indicate SEM. $\boldsymbol{d}-\boldsymbol{f}$, Immunostaining and confocal microscopy of 14 DIV hippocampal neurons nucleofected with pGEPH1 at plating. Neurons were fixed, permeabilized, and stained for gephyrin and VIAAT. Gephyrin RNAi neurons were identified by eGFP expression from the pGEPH1 vector, whereas untransfected neurons in the same culture do not express eGFP. eGFP fluorescence is shown in blue in $\boldsymbol{e} . \boldsymbol{d}, \boldsymbol{e}$, Gephyrin RNAi resulted in abolishment of visible gephyrin staining $(\boldsymbol{d}, \boldsymbol{e})$, gephyrin staining is shown in red in e. Untransfected neurons in the same culture expressed normal gephyrin levels. $f$, The majority of gephyrin clusters (red) in control neurons were colocalized with VIAAT (shown in green). Scale bar, $10 \mu \mathrm{m}$.

extrasynaptic counterparts, suggesting that these distinct receptor pools have differing rates of lateral mobility within the neuronal plasma membrane.

\section{Developing shRNAs to inhibit gephyrin}

Gene knock-out and antisense approaches suggest that the postsynaptic scaffolding protein gephyrin plays a critical role in the clustering of $\mathrm{GABA}_{\mathrm{A}}$ Rs (Essrich et al., 1998; Feng et al., 1998; 
Kneussel et al., 1999, 2001). However, it is unclear whether gephyrin promotes $\mathrm{GABA}_{\mathrm{A}} \mathrm{R}$ cluster formation, or reduces their mobility, thereby enhancing cluster stability. Alternatively, gephyrin may simply act to enhance the global levels of cell surface $\mathrm{GABA}_{\mathrm{A}}$ Rs. To address these issues, we manipulated gephyrin levels in neurons by RNAi, using DNA vectors to generate shRNAs. This methodology has some advantages over studies using gephyrin knock-out animals or an antisense approach. First, gephyrin-deficient homozygous mice die shortly after birth, making studies with cultured neurons difficult (Feng et al., 1998). Whereas both antisense and exogenous short interfering RNAs (siRNAs) are able to suppress protein levels only for a few days, shRNA vectors allow persistent knock-down beyond several weeks. We made several gephyrin-encoding shRNAs under the control of the U6 RNA polymerase III promoter. We first tested RNAi construct efficiency by cotransfecting DsRGep in COS-7 cells and assessing protein levels by Western blotting. Gephyrin RNAi drastically reduced DsRGep expression in COS-7 cells but did not affect endogenous actin levels (Fig. $3 a$ ). For additional experiments, we used the gephyrin shRNA vector that targets a region in the central domain of gephyrin common to all splice variants (for details, see Materials and Methods). We next added eGFP under the CMV promoter to the gephyrin shRNA construct to unambiguously label RNAi cells. This construct (pGEPH1) showed similar efficiency for gephyrin RNAi in COS-7 cells (Fig. 3b). We used pGEPH1 for subsequent experiments in hippocampal neurons. pGEPH1 or a control RNAi construct targeting uncoded sequence (pControl), was nucleofected into hippocampal neurons. After 20 DIV, the pGEPH1expressing neurons had a $45 \pm 5.5 \%$ reduction in gephyrin expression compared with pControl (Fig. 3c). No significant change was seen in the levels of $\beta 3$ subunits, or the $\zeta$ isoform of 14-3-3 (Fig. 3c). The absence of any change in $\beta 3$ levels is consistent with studies on gephyrin knock-out mice (Kneussel et al., 2001). Because nucleofection results in an average transfection efficiency of $40-50 \%$ (Kittler et al., 2004), the $\sim 50 \%$ reduction in gephyrin protein levels is likely to represent RNAi efficiency of $90-100 \%$ at the individual neuron level.

\section{Gephyrin RNAi modifies $\mathrm{GABA}_{\mathrm{A}} \mathrm{R}$ clustering}

We used immunohistochemical analysis of cultured hippocampal neurons followed by confocal microscopy to determine the efficiency of gephyrin RNAi at the cellular level. In 14 DIV neurons that had been nucleofected at plating with pGEPH1, identified by eGFP expression, gephyrin immunoreactivity was absent (Fig. $3 d, e$ ). In contrast, untransfected neurons in the same culture showed abundant gephyrin expression, evident in cell bodies and in neuronal processes (Fig. 3d,e). In stained processes, gephyrin exhibits a highly clustered distribution, with a majority of clusters being apposed to the staining for the vesicular inhibitory amino acid transporter (VIAAT), a specific marker for presynaptic inhibitory specializations (Fig. $3 d, f$ ). This result is consistent with a previous report that showed that, at $10 \mathrm{DIV}, 58 \%$ of gephyrin is colocalized with VIAAT in hippocampal cultures, and this number increases to $90 \%$ by 20 DIV (Danglot et al., 2003). VIAAT clustering over gephyrin RNAi neurons appeared unchanged (Fig. $3 f$ ). To assess the effects of ablating gephyrin expression on the cell surface distribution of $\mathrm{GABA}_{\mathrm{A}} \mathrm{Rs}$, we stained for the $\mathrm{GABA}_{\mathrm{A}} \mathrm{R} \alpha 2$ subunit, because the distribution of this subunit in cultured hippocampal neurons is primarily synaptic and it is highly colocalized with gephyrin (Essrich et al., 1998; Brunig et al., 2002). We costained with VIAAT to quantify the synaptic $\alpha 2$ cluster distribution. Gephyrin RNAi neurons had a $~ 50 \%$ de- a

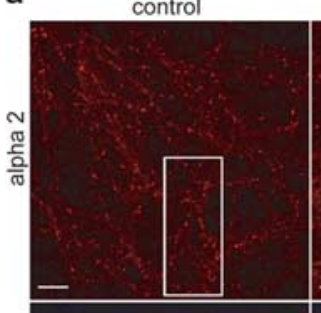

gephyrin RNAi
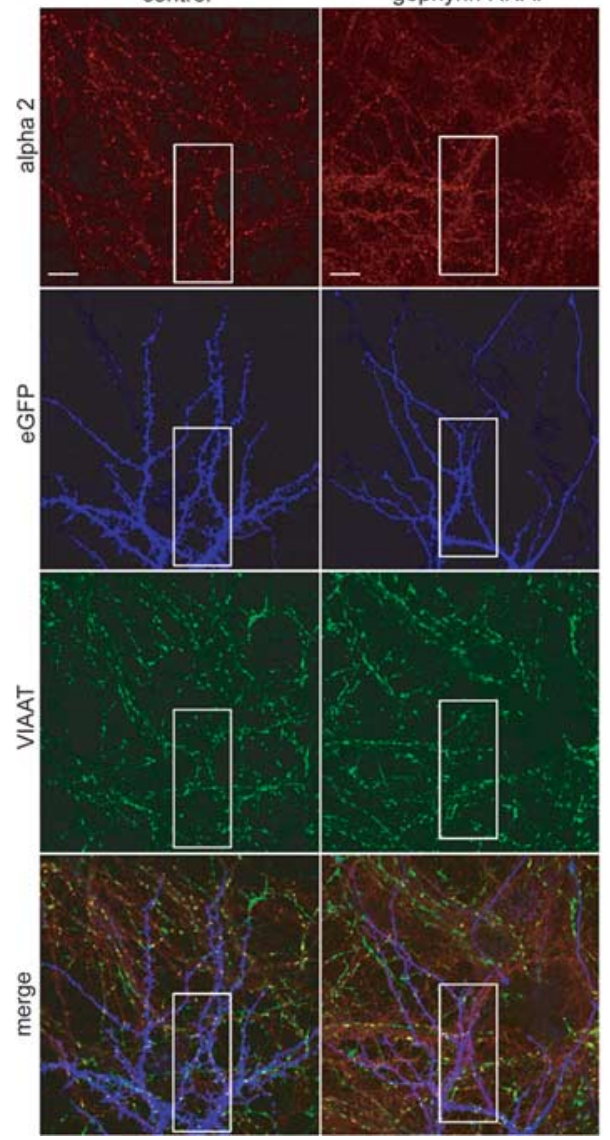

C

Figure 4. Gephyrin RNAi alters synaptic $\alpha 2$ cluster density. $\boldsymbol{a}$, Confocal immunofluorescence microscopy images of 14 DIV hippocampal neurons nucleofected with the gephyrin RNAi vector (pGEPH1) or control (eGFP) and sequentially stained with an antibody to $\alpha 2$ (red) under nonpermeabilized conditions for surface labeling and VIAAT (green) under permeabilized conditions. eGFP fluorescence is shown in blue. Scale bar, $10 \mu \mathrm{m}$. $\boldsymbol{b}$, Gephyrin RNAi neurons (2) showed a $50 \%$ decrease in the density of synaptic $\alpha 2$ clusters compared with control neurons (1) ( $p<0.001$, Student's $t$ test). A total of $24-26$ neurons of each genotype was analyzed from three independent cultures. Error bars indicate SEM. For both control and gephyrin RNAi neurons, an enlargement of the boxed regions in $\boldsymbol{a}$ is shown in $\boldsymbol{b}$ with surface staining of $\alpha 2$ in red and endogenous eGFP fluorescence in blue. The enlarged area shows $\sim 50 \mu \mathrm{m}$ of neuronal processes, corresponding to the unit length quantified for cluster distribution. Note the increased diffuse $\alpha 2$ surface staining in gephyrin RNAi neurons. Scale bar, $10 \mu \mathrm{m}$. c, The density of VIAAT clusters was not significantly changed in gephyrin RNAi neurons (2) compared with control neurons (1). A total of 24-26 neurons of each genotype was analyzed from three independent cultures. Error bars indicate SEM. The asterisk indicates significant difference from control ( $p<0.001$, Student's $t$ test).

crease in synaptic $\alpha 2$ clusters (Fig. $4 a, b$ ), with an observed density of $2.3 \pm 0.2$ clusters $/ 50 \mu \mathrm{m}$ compared with $5.4 \pm 0.3$ clusters $/ 50$ $\mu \mathrm{m}$ in control cultures (mean \pm SEM; $24-26$ neurons counted of each type from three independent cultures). This result is in agreement with previous observations in gephyrin knock-out mice (Kneussel et al., 1999, 2001; Levi et al., 2004) and antisense experiments (Essrich et al., 1998). The decreased density in synaptic $\alpha 2$ clusters was also accompanied by a general increase in diffuse surface staining (Fig. $4 a, b$ ). Interestingly, no significant change was measured in the VIAAT density (Fig. 4c) (gephyrin RNAi neurons, $5.7 \pm 0.4$ clusters $/ 50 \mu \mathrm{m}$; control neurons, $6.4 \pm$ 0.3 clusters $/ 50 \mu \mathrm{m}$ ) (mean \pm SEM; $24-26$ neurons counted of each type from three independent cultures), despite the lack of postsynaptic receptor clusters, similar to previous results on VIAAT immunostaining of spinal cord sections in gephyrin knock- 
a
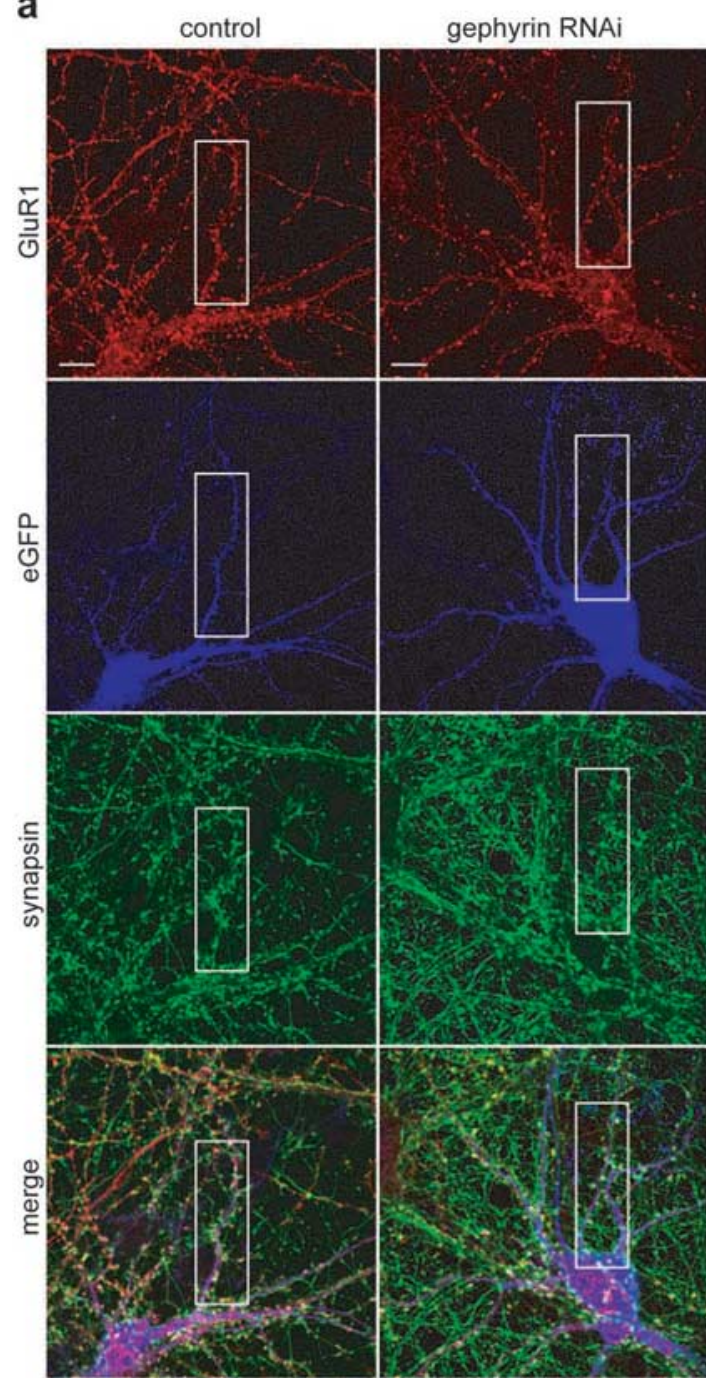

b synaptic GluR1 per $50 \mu \mathrm{m}$

$\begin{array}{llll}0 & 5 & 10 & 15\end{array}$

1

2
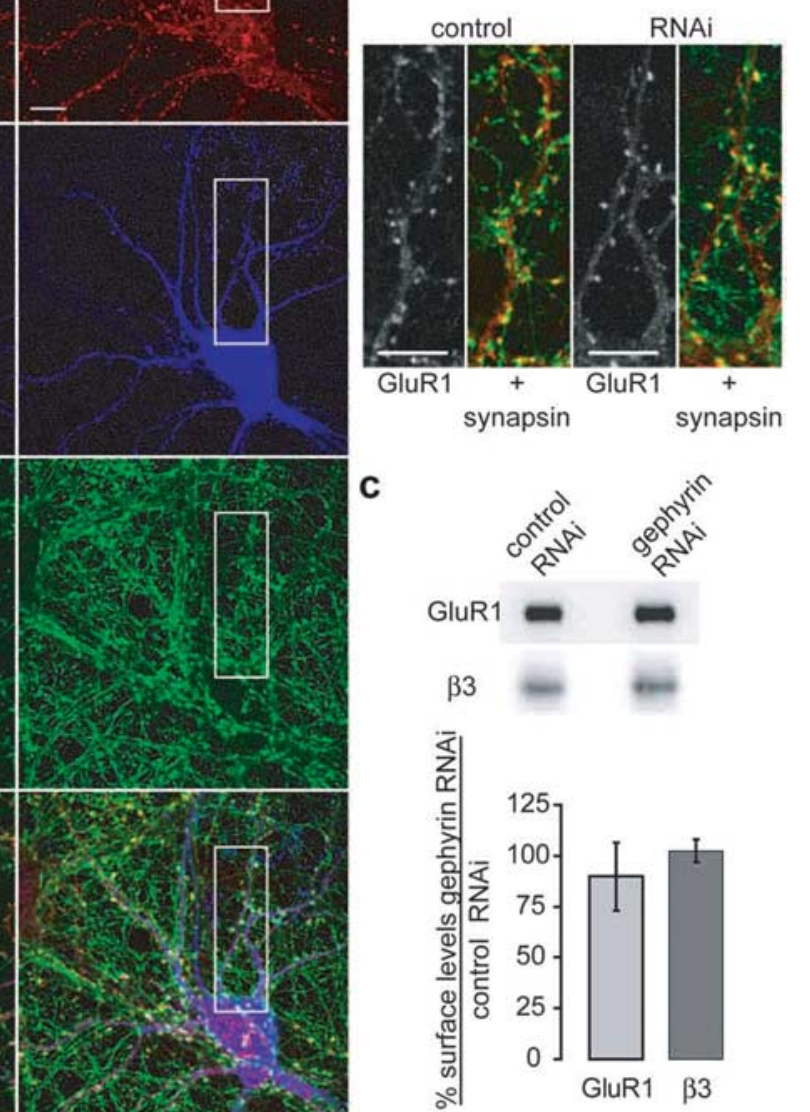

Figure 5. Synaptic GluR1 AMPAR cluster density and total cell surface levels of GluR1-containing AMPAR and $\beta 3$-containing $G_{A B A} R$ are unchanged by gephyrin RNAi. $\boldsymbol{a}$, Confocal immunofluorescence microscopy images of 14 DIV hippocampal neurons nucleofected at plating with the gephyrin RNAi vector (pGEPH1) or control (eGFP) and stained with antibodies to GluR1 AMPAR (red) and synapsin (green). eGFP fluorescence is shown in blue. Scale bar, $10 \mu \mathrm{m}$. $\boldsymbol{b}$, Gephyrin RNAi neurons (2) showed no significant change in synaptic GluR1 AMPAR cluster density compared with control neurons (1). A total of 10 neurons of each genotype was analyzed from three independent cultures. Error bars indicate SEM. For both control and gephyrin RNAi neurons, an enlargement of the boxed regions in $\boldsymbol{a}$ is shown in $\boldsymbol{b}$. The grayscale panel is GluR1 staining, followed by a merged image of GluR1 staining in red and synapsin staining in green. The enlarged area shows $\sim 50 \mu \mathrm{m}$ of neuronal processes. Scale bar, $10 \mu \mathrm{m}$. c, Quantification of $G_{A B A_{A}} R$ total surface levels by biotinylation showed no change in $\beta 3$ subunit-containing receptors or in control GluR1 AMPAR levels. Cell surface biotinylation was performed at $20 \mathrm{DIV}$ from hippocampal neurons nucleofected with the gephyrin RNAi vector (pGEPH1) or a control RNAi vector ( $\mathrm{pControl)}$ at plating. The panel above the histogram shows a representative immunoblot for $\beta 3$ and GluR1. Biotinylation data were obtained from four independent experiments with cultures nucleofected with pGEPH1 and pControl, performed in triplicate. In addition, $50 \mu$ l of neuronal lysate was used to confirm gephyrin protein level knock-down with Western blot analysis for each biotinylation experiment (data not shown). Error bars indicate SEM.

out mice (Kneussel et al., 2001). Quantification of the synaptic GluR1 AMPAR distribution showed no difference between gephyrin RNAi and control cultures: RNAi-treated neurons had a synaptic GluR1 cluster density of $10.7 \pm 0.9$ clusters $/ 50 \mu \mathrm{m}$, whereas control neurons had a cluster density of $11.9 \pm 0.7 / 50$ $\mu \mathrm{m}$ (Fig. 5a,b) (mean \pm SEM; 10 neurons counted of each type from three independent cultures), consistent with qualitative data from gephyrin knock-out mice for the GluR1 (Feng et al., 1998) and GluR2/3 AMPAR subunit (Kneussel et al., 1999).

To determine whether this loss of clusters represented a general decrease in the levels of cell surface $G_{A B A} R$ s in gephyrin
RNAi neurons, we performed cell surface biotinylation of neurons expressing pGEPH1 after 20 DIV. Control cultures expressed a shRNA against eGFP (pControl), because the use of a scrambled siRNA/shRNA is considered to be of little benefit (Editorial, 2003). Biotinylated cell surface proteins were then blotted with an antibody against the $\mathrm{GABA}_{\mathrm{A}} \mathrm{R} \beta 3$ subunit or as a control with an antibody against the AMPAR GluR1 subunit. This approach revealed that, although gephyrin RNAi reduces gephyrin levels, it does not have a significant effect on the number of cell surface $\mathrm{GABA}_{\mathrm{A}}$ Rs containing $\beta 3$ subunits or AMPARs containing GluR1 subunits (Fig. 5c).

Together, these results suggest that gephyrin may not be a prerequisite for the formation of $\mathrm{GABA}_{\mathrm{A}} \mathrm{R}$ clusters but may play a critical role in regulating cluster stability at the cell surface.

\section{Gephyrin regulates $\mathrm{GABA}_{\mathrm{A}} \mathrm{R}$ cluster mobility}

To further investigate the role of gephyrin in cell surface $\mathrm{GABA}_{\mathrm{A}} \mathrm{R}$ cluster stability, we used pHluorin-tagged subunits in a live imaging approach. Initially, our studies focused on receptors containing ${ }^{\mathrm{pHGFP}} \gamma 2$ subunits to visualize the effects of gephyrin RNAi on cell surface $\mathrm{GABA}_{\mathrm{A}} \mathrm{Rs}$. This subunit was chosen, because it exhibits a higher degree of synaptic targeting compared with the $\beta 3$ subunit (Fig. 1b) (Danglot et al., 2003), and the size and distribution of $\gamma 2$ and gephyrin clusters are nearly identical (Danglot et al., 2003). Moreover, previous studies using hippocampal neurons from gephyrin knock-out mice and cultured neurons from wild-type animals treated with antisense oligonucleotides against gephyrin both exhibit specific losses in synaptic clusters of $\mathrm{GABA}_{\mathrm{A}} \mathrm{Rs}$ containing $\gamma 2$ subunits (Essrich et al., 1998; Kneussel et al., 1999, 2001; Levi et al., 2004). For these studies, we used pCON $\gamma 2$, which expresses the ${ }^{\text {PHGFP }} \gamma 2$ subunit alone, and $\mathrm{pGEPH} \gamma 2$, which expresses both the ${ }^{\mathrm{PHGFP}} \gamma 2$ subunit and RNAi against gephyrin. Importantly, $\mathrm{pCON} \gamma 2$ and $\mathrm{pGEPH} \gamma 2$ produced comparable levels of ${ }^{\mathrm{PHGPP}} \gamma 2$ expression as measured by lysates of expressing HEK 293 cells (supplemental Fig. 1h, available at www.jneurosci.org as supplemental material). We first examined the synaptic targeting of the ${ }^{\mathrm{PHGFP}} \gamma 2$ subunit in 14 DIV hippocampal neurons chronically expressing pGEPH $\gamma 2$. In control neurons expressing pCON $\gamma 2$, abundant clusters of ${ }^{\text {pHGFP }} \gamma 2$ subunits were evident, and the majority of these were judged to be synaptic (Figs. 1b;6a,b). In contrast, neurons expressing pGEPH $\gamma 2$ showed a $48.6 \%$ decrease in the density of synaptic receptor clusters containing ${ }^{\mathrm{PHGFP}} \gamma 2$ subunits per $50 \mu \mathrm{m}$ (3.73 \pm 0.35 in gephyrin RNAi neurons compared with $7.68 \pm 0.50$ in 
control cultures) (mean \pm SEM; $8-10$ neurons of each type were analyzed from two to three independent cultures) and an increase in diffuse surface staining (Fig. $6 a-c)$. This effect of RNAi on the clustering of recombinant receptor subunits is reminiscent of our studies on endogenous $\mathrm{GABA}_{\mathrm{A}}$ Rs (Fig. 4), further suggesting a specific role for gephyrin in regulating the stability of receptor clusters on the surface of neurons. To further test this, we examined the effects of reducing gephyrin expression on the mobility of $\mathrm{GABA}_{\mathrm{A}} \mathrm{R}$ clusters on the surface of hippocampal neurons. This necessitated the use of live imaging because it was evident that clusters in neurons expressing pGEPH $\gamma 2$ exhibited significantly enhanced mobility, compromising the use of FRAP. Therefore, we measured the positions of individual clusters at $20 \mathrm{~s}$ intervals over a $4 \mathrm{~min}$ recording period at $37^{\circ} \mathrm{C}$. In control neurons expressing $\mathrm{pCON} \gamma 2$, cell surface clusters of $\mathrm{GABA}_{\mathrm{A}}$ Rs containing ${ }^{\mathrm{pHGFP}} \gamma 2$ subunits exhibited an average velocity of $3.029 \pm 0.702 \times 10^{-3} \mu \mathrm{m} / \mathrm{s}$ (Fig. $7 c$; supplemental movie 2, available at www. jneurosci.org as supplemental material) (mean \pm SEM; $n=8-9$ in three independent experiments). In contrast, neurons expressing pGEPH $\gamma 2$ showed an increased average cluster velocity of $9.011 \pm 1.635 \times$ $10^{-3} \mu \mathrm{m} / \mathrm{s}$ (Fig. $7 c$; supplemental movie 3, available at www.jneurosci.org as supplemental material) (mean \pm SEM; $n=8-9$ in three independent experiments). This value is threefold higher than that seen for ${ }^{\mathrm{pHGFP}} \gamma 2$ subunits under control conditions $(p<0.01)$. Interestingly, the modes of cluster mobility in the absence and presence of gephyrin also appear to be distinct. In the presence of gephyrin, the clusters oscillate around a central axis (Fig. 7a), whereas in neurons expressing RNAi against gephyrin, larger more erratic movements are observed (Fig. 7b).

Finally, we examined the effects of ablating gephyrin on the mobility of $\mathrm{GABA}_{\mathrm{A}} \mathrm{Rs}$ incorporating ${ }^{\mathrm{PHGFP}} \beta 3$ subunits. For these experiments, we used $\mathrm{pCON} \beta 3$ and an additional vector $\mathrm{pGEPH} \beta 3$ that expresses both ${ }_{\mathrm{pHGFP}} \beta 3$ and RNAi against gephyrin. Significantly, immunoblotting of HEK 293 cells revealed that these vectors express equivalent levels of ${ }^{\mathrm{pHGFP}} \beta 3$ (supplemental Fig. $1 g$, available at www.jneurosci.org as supplemental material). In control neurons expressing pCON $\beta 3$, receptor clusters containing ${ }^{\mathrm{pHGFP}} \beta 3$ have an average velocity of $2.752 \pm$ $0.338 \times 10^{-3} \mu \mathrm{m} / \mathrm{s}$ (mean \pm SEM; $n=8-9$ in three independent experiments), very similar to values seen for clusters incorporating ${ }^{\mathrm{pHGFP}} \gamma 2$ subunits (Fig. $7 c$ ). In contrast, ${ }^{\mathrm{pHGFP}} \beta 3$ clusters in neurons expressing pGEPH $\beta 3$ exhibit a higher mobility of $9.067 \pm 2.698 \times$ $10^{-3} \mu \mathrm{m} / \mathrm{s}$ (mean \pm SEM; $n=8-9$ in three independent

a Scale bar, $10 \mu \mathrm{m}$.
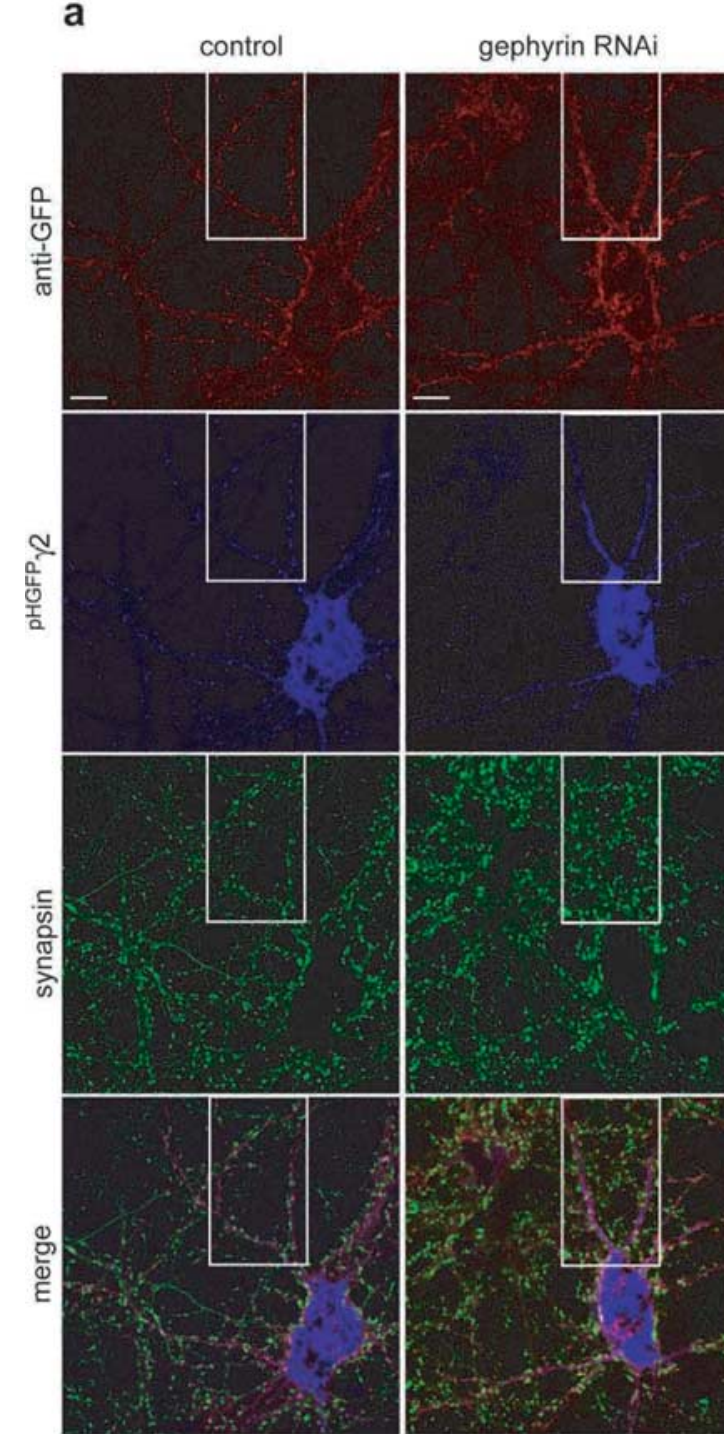

b

control

gephyrin

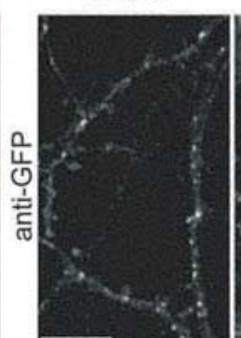
RNAi
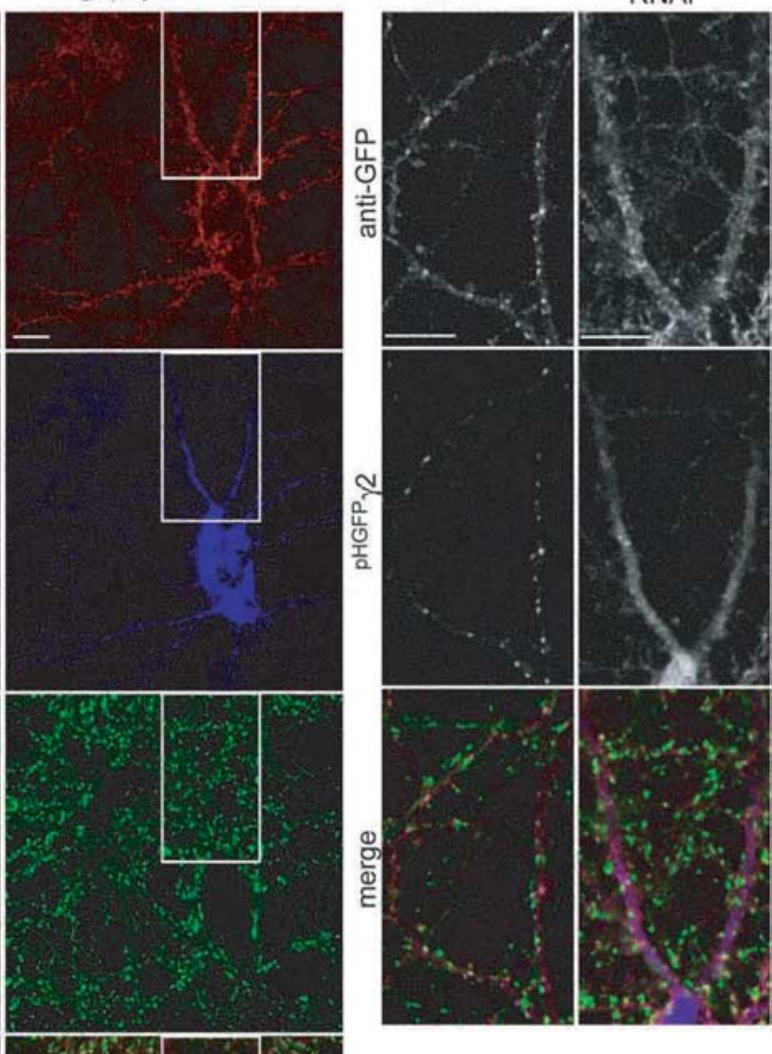

C synaptic $\gamma 2$ clusters per $50 \mu \mathrm{m}$

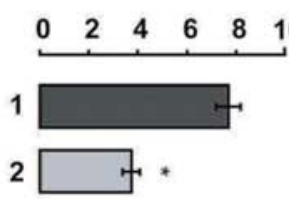

Figure 6. Chronic gephyrin RNAi reduces clustering of $\mathrm{GABA}_{\mathrm{A}} \mathrm{Rs} \mathrm{containing}^{\mathrm{pHGFP}} \gamma 2$ subunits. $\boldsymbol{a}$, Confocal microscope images of 14 DIV hippocampal neurons nucleofected with pGEPH $\gamma 2$ (encoding both ${ }^{\text {PHGFP }} \gamma 2$ and the gephyrin RNAi hairpin, labeled as gephyrin RNAi) or pCON $\gamma 2$ (encoding ${ }^{\text {PHGFP }} \gamma 2$ alone, labeled as control) and sequentially stained with an antibody to GFP under nonpermeabilized conditions for surface labeling (shown in red) and synapsin under permeabilized conditions (shown in green). Because the anti-GFP antibody used for surface labeling of ${ }^{\text {PHGPP }} \gamma 2$ was a polyclonal antibody, monoclonal anti-synapsin was used as a presynaptic marker for these experiments. GABA $A_{A}$ Rs containing ${ }^{\text {PHGPP }} \gamma 2$ are expressed at the cell surface and localized to synaptic sites. Long-term gephyrin RNAi leads to loss of ${ }^{\text {PHGFP }} \gamma 2$ receptor clusters and an increase in the diffuse surface distribution of ${ }^{\mathrm{PHGP}} \gamma 2$-containing receptors. Because the final fixed tissue shown here is permeabilized and maintained at a $\mathrm{pH}$ of 6.8, endogenous ${ }^{\text {pHGFP }} \gamma 2$ fluorescence in $\boldsymbol{a}$ and $\boldsymbol{b}$ is visible for both cell surface and intracellular receptor pools (shown in blue). Scale bar, $10 \mu \mathrm{m} . \boldsymbol{b}, \boldsymbol{c}$, Gephyrin RNAi neurons (2) showed a $48.6 \%$ decrease in the density of synaptic ${ }^{\text {pHGFP }} \gamma 2$ clusters compared with control neurons (1) ( $p<0.001$, Student's $t$ test). A total of $8-10$ neurons of each genotype was analyzed per culture ( $n=$ $2-3$ cultures). Error bars indicate SEM. For both control and gephyrin RNAi neurons, an enlargement of the boxed regions in $\boldsymbol{a}$ is shown in $\boldsymbol{b}$. The first enlargement panel shows a grayscale image of surface ${ }^{\text {PHGPP }} \gamma 2$ staining with anti-GFP antibody under nonpermeabilized conditions, followed by a grayscale image of endogenous pHluorin fluorescence of ${ }^{\text {pHGFP }} \gamma 2$. As in $\boldsymbol{a}$, the merged image shows surface ${ }^{\text {pHGFP }} \gamma 2$ staining in red, endogenous ${ }^{\text {PHGFP }} \gamma 2$ fluorescence in blue, and synapsin staining in green. The enlarged area shows $\sim 50 \mu \mathrm{m}$ of neuronal processes, corresponding to the unit length quantified for cluster distribution.

experiments). This value is significantly higher than that seen in control neurons $(p<0.01)$, and similar to that seen for receptor clusters incorporating $\gamma 2$ subunits in the absence of gephyrin $\left(9.011 \pm 1.635 \times 10^{-3} \mu \mathrm{m} / \mathrm{s}\right.$; Fig. $\left.7 c\right)$.

Together, these observations with both pHluorin-tagged $\gamma 2$ and $\beta 3$ subunits are consistent with a critical role for gephyrin in regulating the lateral mobility of $\mathrm{GABA}_{\mathrm{A}} \mathrm{R}$ clusters. 
a

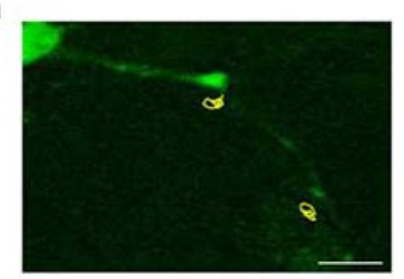

b

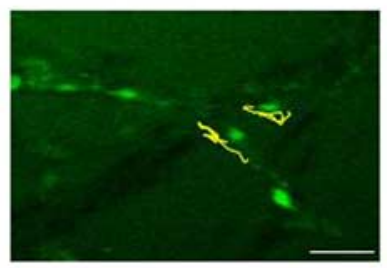

c

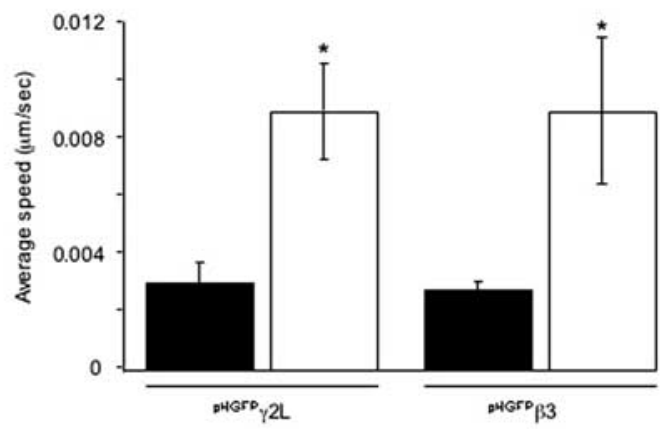

Figure 7. Gephyrin regulates the lateral mobility of $G_{A B A}$ R clusters containing ${ }^{\text {pHGFP }} \gamma 2$ or ${ }^{\text {pHGFP }} \beta 3$ subunits. $\boldsymbol{a}, \boldsymbol{b}$, Live imaging of $\mathrm{GABA}_{\mathrm{A}} \mathrm{R}$ clusters in transfected neurons. Images were acquired from neurons expressing ${ }^{\text {pHGFP }} \gamma 2$ subunits under control conditions $(\boldsymbol{a})$ or in the presence of gephyrin RNAi $(\boldsymbol{b})$, using vectors $\mathrm{pCON} \gamma 2$ and $\mathrm{pGEPH} \gamma 2$, respectively. Overlaid traces of individual ${ }^{\text {pHGFP }} \gamma 2$ cluster movements recorded during a 4 min period, with images acquired every 20 s are shown in yellow traces. ${ }^{\text {pHGFP }} \gamma 2$ clusters in control neurons show little movement (see supplemental movie 2, available at www.jneurosci.org as supplemental material), whereas mobility was dramatically increased in gephyrin RNAi neurons (see supplemental movie 3, available at www.jneurosci.org as supplemental material). Scale bars, $5 \mu \mathrm{m}$. c, Gephyrin regulates the mobility of $G A B A_{A} R$ clusters. The average speed in micrometers per second for $G_{A B A_{A} R}$ clusters containing ${ }^{\text {pHGFP }} \gamma 2$ or ${ }^{\text {pHGFP }} \beta 3$ subunits under control conditions ( $\square$ ) and gephyrin RNAi $(\square)$ was determined using data derived from live imaging. Gephyrin RNAi results in enhanced velocity for $\mathrm{GABA}_{A} \mathrm{R}$ clusters containing either ${ }^{\text {pHGFP }} \gamma 2$ and ${ }^{\text {pHGFP }} \beta 3$ subunits. *Significantly different from control ( $p<0.01$, Student's $t$ test; $n=8-9$ in 3 independent experiments). Error bars indicate SEM.

\section{Discussion}

Using FRAP, we have compared the relative mobilities of synaptic and extrasynaptic $\mathrm{GABA}_{\mathrm{A}} \mathrm{R}$ pools in hippocampal neurons. Our results revealed that extrasynaptic receptors exhibited rapid rates of FRAP that reached $50 \%$ of the initial intensity within $15 \mathrm{~min}$. Moreover, the rate of FRAP in neurons was found to be slower for central domains within photobleached areas compared with peripheral regions. Together, these observations demonstrate that FRAP in our experiments is dependent on mobility of $\mathrm{GABA}_{\mathrm{A}} \mathrm{Rs}$ from unbleached areas, rather than intracellular trafficking. This is consistent with just-published electrophysiological data showing dynamic lateral mobility of $\mathrm{GABA}_{\mathrm{A}} \mathrm{R}$ between extrasynaptic and synaptic locations restoring synapse function (Thomas et al., 2005).

In our studies, FRAP for synaptic receptors was found to be approximately threefold lower than that observed for extrasynaptic receptors over the same time period. Although FRAP is an average measure of population dynamics, in contrast to singleparticle tracking of individual receptors, our results are consistent with lower rates of lateral mobility for $\mathrm{GABA}_{\mathrm{A}} \mathrm{Rs}$ at inhibitory synapses compared with their extrasynaptic equivalents. This strongly suggests the selective reduction of $\mathrm{GABA}_{\mathrm{A}} \mathrm{R}$ lateral mobility at inhibitory postsynaptic specializations. Similar mechanisms have recently been postulated to be responsible for the accumulation of both glutamate and glycine receptors at synaptic sites (Dahan et al., 2003; Groc et al., 2004).

The selective confinement of $\mathrm{GABA}_{\mathrm{A}}$ Rs at inhibitory synapses is likely to be regulated by both presynaptic and postsynaptic mechanisms. With regard to possible postsynaptic mechanisms, a number of $\mathrm{GABA}_{\mathrm{A}} \mathrm{R}$-interacting proteins have been identified recently, including GABARAP $\left(\mathrm{GABA}_{\mathrm{A}} \mathrm{R}\right.$-associated protein), PLIC-1 (homolog of the yeast DSK protein), and HAP1 (huntingtin-associated protein-1) (Wang et al., 1999; Bedford et al., 2001; Kittler et al., 2004). Although interaction with these binding partners has been established to regulate receptor trafficking within the endocytic and secretory pathways, they do not appear to facilitate receptor accumulation at inhibitory synapses. In contrast, gephyrin, a protein that is critical for regulating the clustering of glycine receptors and the synthesis of molybdenum cofactor, also appears to be of significance in controlling the accumulation of $\mathrm{GABA}_{\mathrm{A}} \mathrm{Rs}$ at synaptic sites (Kneussel and Betz, 2000a; Kittler and Moss, 2003). Gephyrin is enriched at GABAergic postsynaptic specializations throughout the CNS, and moreover gene knock-out and antisense approaches have revealed that reducing gephyrin expression compromises the accumulation of $\mathrm{GABA}_{\mathrm{A}} \mathrm{R}$ subtypes containing $\alpha 2$ or $\gamma 2$ subunits at inhibitory synapses (Essrich et al., 1998; Kneussel et al., 1999, 2001; Levi et al., 2004).

To further assess the role of gephyrin in the construction of inhibitory synapses, we used plasmid-based RNAi to selectively modify expression levels of this protein in hippocampal neurons (Hannon and Rossi, 2004). Using this approach, we were able to abolish gephyrin expression in transfected neurons as measured using immunohistochemistry. This loss of gephyrin expression significantly reduced, but did not completely abolish, the clustering of $\mathrm{GABA}_{\mathrm{A}}$ receptors containing $\alpha 2$ or $\gamma 2$ subunits at synaptic sites, without altering the density of presynaptic innervation (Essrich et al., 1998; Kneussel et al., 1999, 2001; Levi et al., 2004). Using biochemical analysis, we were able to further establish that this reduction of receptor clustering in the absence of gephyrin did not result from a general decrease in $\mathrm{GABA}_{\mathrm{A}} \mathrm{R}$ expression levels or a reduction in cell surface number. Together, these observations suggest that gephyrin per se is not an essential requirement for the formation of $\mathrm{GABA}_{\mathrm{A}} \mathrm{R}$ clusters, but may act to specifically regulate the stability of $\mathrm{GABA}_{\mathrm{A}}$ receptor clusters.

To further address the role of gephyrin in regulating accumulation of $\mathrm{GABA}_{\mathrm{A}} \mathrm{R}$ at inhibitory synapses, we used real-time imaging to compare the mobility of receptor clusters in the presence and absence of gephyrin. In the presence of endogenous gephyrin, $\mathrm{GABA}_{\mathrm{A}} \mathrm{R}$ clusters containing either ${ }^{\mathrm{PHGFP}} \gamma 2$ or ${ }^{\mathrm{PHGFP}} \beta 3$ subunits exhibited low rates of mobility on the cell surface. In contrast, ${ }^{\mathrm{PHGFP}} \gamma 2$ and ${ }^{\mathrm{PHGFP}} \beta 3$ subunit-containing $\mathrm{GABA}_{\mathrm{A}} \mathrm{R}$ clusters formed in the absence of gephyrin demonstrated threefold higher levels of mobility. Therefore, our results are consistent with a specific role for gephyrin in restricting the mobility of $\mathrm{GABA}_{\mathrm{A}} \mathrm{R}$ clusters on the cell surface of neurons and thereby promoting $\mathrm{GABA}_{\mathrm{A}} \mathrm{R}$ accumulation at inhibitory synapses.

The precise mechanism underlying the effects of gephyrin on stabilization of $\mathrm{GABA}_{\mathrm{A}} \mathrm{R}$ clusters remains to be determined. Gephyrin has been shown to self-associate into trimeric structures (Sola et al., 2001, 2004; Schrader et al., 2004), which is believed to contribute to the molecular basis underlying the ability of this protein to act as a molecular scaffold at inhibitory synapses (Kneussel and Betz, 2000b; Xiang et al., 2001). In addition, gephyrin interacts with microtubules, regulators of the actin cytoskeleton, and directly binds to glycine receptors and thereby anchors these receptors to the cytoskeleton at synaptic sites 
(Kneussel and Betz, 2000a). However, to date, it has not been possible to demonstrate direct binding of $\mathrm{GABA}_{\mathrm{A}}$ Rs to gephyrin, suggesting that this interaction may be mediated by intermediate protein(s) or via labile covalent modifications of either protein.

Together, our studies illustrate for the first time that synaptic and extrasynaptic $\mathrm{GABA}_{\mathrm{A}}$ Rs have differing levels of confinement on the surface of hippocampal neurons. Moreover, our results highlight a novel role for the inhibitory postsynaptic protein gephyrin in reducing $\mathrm{GABA}_{\mathrm{A}} \mathrm{R}$ diffusion, thereby enhancing $\mathrm{GABA}_{\mathrm{A}} \mathrm{R}$ accumulation at inhibitory synapses. Our data support the emerging model of regulated lateral diffusion (Triller and Choquet, 2005), where differences in receptor surface dynamics are likely to be critical during synaptogenesis but could also be part of a general mechanism for regulation of synaptic strength.

\section{References}

Amato A, Connolly CN, Moss SJ, Smart TG (1999) Modulation of neuronal and recombinant GABAA receptors by redox reagents. J Physiol (Lond) 517:35-50.

Ashby MC, Ibaraki K, Henley JM (2004a) It's green outside: tracking cell surface proteins with pH-sensitive GFP. Trends Neurosci 27:257-261.

Ashby MC, De La Rue SA, Ralph GS, Uney J, Collingridge GL, Henley JM (2004b) Removal of AMPA receptors from synapses is preceded by transient endocytosis of extrasynaptic AMPARs. J Neurosci 24:5172-5176.

Banker G, Goslin K (1998) Culturing nerve cells, Ed 2. Cambridge, MA: MIT.

Bedford FK, Kittler JT, Muller E, Thomas P, Uren JM, Merlo D, Wisden W, Triller A, Smart TG, Moss SJ (2001) GABA receptor cell surface number and subunit stability are regulated by the ubiquitin-like protein Plic-1. Nat Neurosci 4:908-916.

Brunig I, Scotti E, Sidler C, Fritschy JM (2002) Intact sorting, targeting, and clustering of gamma-aminobutyric acid A receptor subtypes in hippocampal neurons in vitro. J Comp Neurol 443:43-55.

Crestani F, Lorez M, Baer K, Essrich C, Benke D, Laurent JP, Belzung C, Fritschy JM, Luscher B, Mohler H (1999) Decreased GABAA-receptor clustering results in enhanced anxiety and a bias for threat cues. Nat Neurosci 2:833-839.

Dahan M, Levi S, Luccardini C, Rostaing P, Riveau B, Triller A (2003) Diffusion dynamics of glycine receptors revealed by single-quantum dot tracking. Science 302:442-445.

Danglot L, Triller A, Bessis A (2003) Association of gephyrin with synaptic and extrasynaptic GABAA receptors varies during development in cultured hippocampal neurons. Mol Cell Neurosci 23:264-278.

Editorial (2003) Whither RNAi? Nat Cell Biol 5:489-490.

Essrich C, Lorez M, Benson JA, Fritschy JM, Luscher B (1998) Postsynaptic clustering of major GABAA receptor subtypes requires the gamma 2 subunit and gephyrin. Nat Neurosci 1:563-571.

Feng G, Tintrup H, Kirsch J, Nichol MC, Kuhse J, Betz H, Sanes JR (1998) Dual requirement for gephyrin in glycine receptor clustering and molybdoenzyme activity. Science 282:1321-1324.

Groc L, Heine M, Cognet L, Brickley K, Stephenson FA, Lounis B, Choquet D (2004) Differential activity-dependent regulation of the lateral mobilities of AMPA and NMDA receptors. Nat Neurosci 7:695-696.

Hannon GJ, Rossi JJ (2004) Unlocking the potential of the human genome with RNA interference. Nature 431:371-378.

Jovanovic JN, Thomas P, Kittler JT, Smart TG, Moss SJ (2004) Brainderived neurotrophic factor modulates fast synaptic inhibition by regulating $\mathrm{GABA}_{\mathrm{A}}$ receptor phosphorylation, activity, and cell-surface stability. J Neurosci 24:522-530.

Kittler JT, Moss SJ (2003) Modulation of GABAA receptor activity by phosphorylation and receptor trafficking: implications for the efficacy of synaptic inhibition. Curr Opin Neurobiol 13:341-347.

Kittler JT, Wang J, Connolly CN, Vicini S, Smart TG, Moss SJ (2000a) Analysis of GABAA receptor assembly in mammalian cell lines and hippocampal neurons using gamma 2 subunit green fluorescent protein chimeras. Mol Cell Neurosci 16:440-452.

Kittler JT, Delmas P, Jovanovic JN, Brown DA, Smart TG, Moss SJ (2000b) Constitutive endocytosis of GABAA receptors by an association with the adaptin AP2 complex modulates inhibitory synaptic currents in hippocampal neurons. J Neurosci 20:7972-7977.
Kittler JT, Thomas P, Tretter V, Bogdanov YD, Haucke V, Smart TG, Moss S (2004) Huntingtin-associated protein 1 regulates inhibitory synaptic transmission by modulating $\gamma$-aminobutyric acid type A receptor membrane trafficking. Proc Natl Acad Sci USA 101:12736-12741.

Kneussel M, Betz H (2000a) Receptors, gephyrin and gephyrin-associated proteins: novel insights into the assembly of inhibitory postsynaptic membrane specializations. J Physiol (Lond) 525:1-9.

Kneussel M, Betz H (2000b) Clustering of inhibitory neurotransmitter receptors at developing postsynaptic sites: the membrane activation model. Trends Neurosci 23:429-435.

Kneussel M, Brandstatter JH, Laube B, Stahl S, Muller U, Betz H (1999) Loss of postsynaptic $\mathrm{GABA}_{\mathrm{A}}$ receptor clustering in gephyrin-deficient mice. J Neurosci 19:9289-9297.

Kneussel M, Brandstatter JH, Gasnier B, Feng G, Sanes JR, Betz H (2001) Gephyrin-independent clustering of postsynaptic $\mathrm{GABA}_{\mathrm{A}}$ receptor subtypes. Mol Cell Neurosci 17:973-982.

Lagnado L, Gomis A, Job C (1996) Continuous vesicle cycling in the synaptic terminal of retinal bipolar cells. Neuron 17:957-967.

Levi S, Logan SM, Tovar KR, Craig AM (2004) Gephyrin is critical for glycine receptor clustering but not for the formation of functional GABAergic synapses in hippocampal neurons. J Neurosci 24:207-217.

Mammen AL, Huganir RL, O’Brien RJ (1997) Redistribution and stabilization of cell surface glutamate receptors during synapse formation. J Neurosci 17:7351-7358.

Meier J, Vannier C, Serge A, Triller A, Choquet D (2001) Fast and reversible trapping of surface glycine receptors by gephyrin. Nat Neurosci 4:253-260.

Miesenbock G, De Angelis DA, Rothman JE (1998) Visualizing secretion and synaptic transmission with $\mathrm{pH}$-sensitive green fluorescent proteins. Nature 394:192-195.

Mohrmann R, Lessmann V, Gottmann K (2003) Developmental maturation of synaptic vesicle cycling as a distinctive feature of central glutamatergic synapses. Neuroscience 117:7-18.

Moss SJ, Smart TG (2001) Constructing inhibitory synapses. Nat Rev Neurosci 2:240-250.

Nuutila J, Lilius EM (2005) Flow cytometric quantitative determination of ingestion by phagocytes needs the distinguishing of overlapping populations of binding and ingesting cells. Cytometry A 65A:93-102.

Rathenberg J, Kittler JT, Moss SJ (2004) Palmitoylation regulates the clustering and cell surface stability of GABAA receptors. Mol Cell Neurosci 26:251-257.

Schrader N, Kim EY, Winking J, Paulukat J, Schindelin H, Schwarz G (2004) Biochemical characterization of the high affinity binding between the glycine receptor and gephyrin. J Biol Chem 279:18733-18741.

Scotti AL, Reuter H (2001) Synaptic and extrasynaptic gammaaminobutyric acid type A receptor clusters in rat hippocampal cultures during development. Proc Natl Acad Sci USA 98:3489-3494.

Sieghart W, Sperk G (2002) Subunit composition, distribution and function of $\mathrm{GABA}_{\mathrm{A}}$ receptor subtypes. Curr Top Med Chem 2:795-816.

Sola M, Kneussel M, Heck IS, Betz H, Weissenhorn W (2001) X-ray crystal structure of the trimeric N-terminal domain of gephyrin. J Biol Chem 276:25294-25301.

Sola M, Bavro VN, Timmins J, Franz T, Ricard-Blum S, Schoehn G, Ruigrok RW, Paarmann I, Saiyed T, O’Sullivan GA, Schmitt B, Betz H, Weissenhorn W (2004) Structural basis of dynamic glycine receptor clustering by gephyrin. EMBO J 23:2510-2519.

Thomas P, Mortensen M, Hosie AM, Smart TG (2005) Dynamic mobility of functional $\mathrm{GABA}_{\mathrm{A}}$ receptors at inhibitory synapses. Nat Neurosci 8:889-897.

Triller A, Choquet D (2003) Synaptic structure and diffusion dynamics of synaptic receptors. Biol Cell 95:465-476.

Triller A, Choquet D (2005) Surface trafficking of receptors between synaptic and extrasynaptic membranes: and yet they do move! Trends Neurosci 28:133-139.

Wang H, Bedford FK, Brandon NJ, Moss SJ, Olsen RW (1999) GABA $\mathrm{A}^{-}$ receptor-associated protein links $\mathrm{GABA}_{\mathrm{A}}$ receptors and the cytoskeleton. Nature 397:69-72.

Xiang S, Nichols J, Rajagopalan KV, Schindelin H (2001) The crystal structure of Escherichia coli MoeA and its relationship to the multifunctional protein gephyrin. Structure (Camb) 9:299-310. 